\title{
Waste Water Use in Crop Production: A Review
}

\author{
M. P. S. Khurana ${ }^{1, *}$, Pritpal Singh ${ }^{2}$ \\ ${ }^{1}$ Department of Soils, Punjab Agricultural University, Ludhiana, Punjab,141 004, India \\ ${ }^{2}$ Krishi Vigy an Kendra (PAU), Haveli Kalan, Ropar, Punjab, 140 001, India
}

\begin{abstract}
Paucity of quality fresh water for agriculture has made waste water (WW) application a popular option. Available data on chemical composition of diffe rent waste water, their effect on soil fertility, soil heavy-metal content, crop yield and quality parameters and maximum permissible limits (MPL) of different International environment protection agencies and governments of different countries has been summarized. Chemical composition of WW varied remarkably with respect to their heavy-metal content, $\mathrm{pH}$, electrical conductivity (EC), biolog ical oxidation demand (BOD), chemical oxidation demand (COD), a kalinity and hardness. Field application of all types of waste water significantly increases soil OC percentage, soil EC, cation exchange capacity (CEC), total and DTPA-extractable heavy-metal/mic ro-nutrient content, available macro-nutrient (, P and $\mathrm{K}$ ) content with significant decreases in calcium carbonate content of surface soil. However, high content of nitrogen, phosphorus and potassium strengthens its high fertigation/manural value for field crops. Significantly higher heavy-metal accumulation in soils irrigated with WW than ground water has been observed in surface layer than the lower depths of soil profile. Since crop genotypes and even crop cultivars within genotypes respond differently to waste water irrigation, their selection becomes more important under such situations. More importantly, carbon sequestration through WW irrigation could sustain long-term soil fertility. Periodic monitoring of chemical composition of waste water, soil and crop produce is however, suggested for safe and long term use of waste water.
\end{abstract}

Keywords Crop Yield, Ground Water (GW), Heavy-metals, Maximum Permissible Limits (MPL), Micro-nutrients, Waste Water (WW)

\section{Introduction}

Water is a vital to all living creature, as it makes up to $50-97 \%$ of plant and animal and about $70 \%$ of average human body weight[1], but regrettably it is the most poorly managed resource in the World[2]. Ground water (GW) resources in most areas of world are shrinking at an alarming rate and may not meet the ever increasing demands from agriculture and industry in future. Estimates revelled that agriculture sector consumes maximum of the GW and $\sim 80$ per cent of actual water resources are utilized in agriculture for irrigation purpose. Many farmers in areas near to urban/per-urban localities are even compelled to use waste water to irrigate their crops, due to absence of better alternatives [3].

The implications associated with heavy-metal contamination are of great significance, particularly in agricultural production system. Tremendously escalating human population and expanding industry and urbanization has not only used a large area of World productive lands, but is also generating a large volume of WW every day. Estimates revealed an annual production of $\sim 30$ million tons

* Corresponding author:

khuranamps1@hotmail.com (M. P. S. Khurana)

Published online at http://journal.sapub.org/re

Copyright (C) 2012 Scientific \& Academic Publishing. All Rights Reserved of WW in the World, of which $\sim 70 \%$ is consumed as an agricultural fertilizer and irrigation source[4]. With that WW utilization for crop production has gained an acceptance, all over the World[5] as an economic alternate that could substitute nutrient needs [6-9] and water requirement of crop plants. It India, estimates revealed that $\sim 73,000$ hectares were irrigated with $\mathrm{WW}$ during early nineties and presently the area under WW irrigation is on the rise[10].

Many small to medium scale industries operating in peri-urban residential areas of old cities are disposing their contaminated effluents directly in sewage system. Nutrients and water being the most critical input in agriculture, harvesting the nutrients and irrigation potential of WW are of prime importance for maximizing the food, fodder and fuel production. Even, the conservative estimates on the basis of $70 \%$ of the sewage available from large cities, shows that these effluents have the potential for irrigating $(7.5 \mathrm{~cm})$, about 21 thousands hectares of land on daily basis or alternately about 7.8 million ha on annual basis[11]. Studies have documented that direct disposal of effluents to land and water bodies has potential to conta minate air, surface, GW as well as soils and crops grown on these soils which will have bearing on human health. Possibilities of GW (shallow tube-well) pollution with respect to heavy-metal concentrations by WW application have also been suspected[12]. Therefore, an attempt has been made to summarize the information available in the published 
literature to construct a balance sheet of beneficial and harmful effects of WW application in soil-plant-water system for sustainable crop productivity.

\section{Fertigation / Manurial Value of Waste Water}

Waste water has been considered as low price fertilizer because of its high nitrogen $(\mathrm{N})$, phosphorus $(\mathrm{P})$ and potassium $(\mathrm{K})$ content[8]. Although of wide variation in nutrient concentrations, WW[13] contained 48.3, 7.6, 72.4 and $34.6 \mathrm{mg} \mathrm{L}^{-1}$ of N, P, K and sulphur (S) besides their micro-nutrient manural value $\left(0.34 \mathrm{mg} \mathrm{Zn} \mathrm{L}{ }^{-1}, 10.8 \mathrm{mg} \mathrm{Fe}\right.$ $\mathrm{L}^{-1}, 0.2 \mathrm{mg} \mathrm{Cu} \mathrm{L}^{-1}$ and $0.36 \mathrm{mg} \mathrm{Mn} \mathrm{L}^{-1}$ ). Thus, five irrigations of $7.5 \mathrm{~cm}$ each with SW could add about 181,29, 270 and $130 \mathrm{~kg} \mathrm{ha}^{-1}$ of N, P, K and S, respectively which is adequate to meet the nutrient requirement of the crops. Computations made on the basis of an average content of $\mathrm{N}, \mathrm{P}$ and $\mathrm{K}$ in WW and $\sim 70 \%$ utilization in agriculture sector shows that WW can annually contribute $380,60,520$ and 1.4 thousand tons of $\mathrm{N}, \mathrm{P}, \mathrm{K}$ and $\mathrm{Zn}$, respectively, in addition to other micro-nutrients. The total value of these nutrients would be around 1.78 million US\$ annually [11]. These findings thus, recapitulates that WW have great potential as manure when used for irrigation to crops.

\section{Maximum Permissible Level of Heavy-metals and Other Quality Related Parameters}

Tables 1 and 2 report information on maximum permissible level(MPL) of heavy-metals and other pollution related parameters of WW for its use as irrigation purpose, standardized by different agencies in different countries. Governments of different countries and the agencies/ organizations associated with protection of environment (Tables 1 and 2) have suggested a wide range of $\mathrm{WW} \mathrm{pH}$ (6.0-9.0) for agricultural use. Total concentration of soluble salts (EC) should be in between 3.0-5.0 dS m$~^{-1}$, a MPL suggested by different agencies/Governments (Tables 1 and 2). Wide variation in MPL for sodium adsorption ratio (SAR) $v i z$. as low as $<1.0[14], 6.0-9.0[15], 10.0[16]$ to as high as $150[17]$ has been suggested. Likewise, the hardness of the WW for their use in agriculture as irrigation purpose should fall in between $200-600 \mathrm{mg} \mathrm{L}^{-1}[14,18]$. Concentration of total suspended solids (TSS) in WW should be $<400 \mathrm{mg}$ $\mathrm{L}^{-1}[16],<300 \mathrm{mg} \mathrm{L}^{-1}$ (Tokyo standards) and $<100 \mathrm{mg} \mathrm{L}^{-1}[19]$. Standards of National Environmental Quality Standards, Pakistan (NEQS) [20] has set $10 \mathrm{mg} \mathrm{L}^{-1}$ as a MPL for oil and grease, while according to Gazette of Mauritius[16] a value of $150 \mathrm{mg} \mathrm{L}^{-1}$ for oil and grease has been standardized as safe for WW use in agriculture. Tokyo standards revealed that phenolic compound concentration in WW should be less than $5.0 \mathrm{mg} \mathrm{L}^{-1}$, for irrigation purpose. A wide range (from
30.0 to $120.0 \mathrm{mg} \mathrm{L}^{-1}$ ) of total nitrogen (TN) in WW for agricultural use has been standardized by different agencies/Governments (Tables 1 and 2). Nitrate- $\mathrm{N}\left(\mathrm{NO}_{3}-\mathrm{N}\right)$ concentration in WW should not exceed $120 \mathrm{mg} \mathrm{L}^{-1}$ (Tokyo Standards), $80 \mathrm{mg} \mathrm{L}^{-1}[16], 20 \mathrm{mg} \mathrm{L}^{-1}$ [18], $10 \mathrm{mg} \mathrm{L}^{-1}$ [14] and $5.0 \mathrm{mg} \mathrm{L}^{-1}[21]$ for safe use as irrigation purpose. Far less cut-off concentration for ammonical- $\mathrm{N}\left(\mathrm{NH}_{4}-\mathrm{N}\right)$ as $0.2 \mathrm{mg}$ $\mathrm{L}^{-1}[14,18]$ in contrast to far high concentration of $5.0 \mathrm{mg}$ $\mathrm{L}^{-1}[21]$ has been suggested. Wide variation in MPL for sulphate-S $\left(\mathrm{SO}_{4}{ }^{2-}-\mathrm{S}\right)$ concentration in WW from $21-1500 \mathrm{mg}$ $\mathrm{L}^{-1}$ has been standardized by different agencies Tremendously escalating human population and expanding industry and urbanization has not only used a large area of World productive lands, but is also generating a large volume of WW every day (Tables 1 and 2). Concentration of $\mathrm{Mn}$ in WW from 0.2 to $10 \mathrm{mg} \mathrm{L}^{-1}$ (Tables 1 and 2) has been referred as safe limit for agricultural use by different agencies/Governments. Zinc concentration should be $<5.0$ $\mathrm{mg} \mathrm{L}^{-1}$ in WW for irrigation use. Likewise, $\mathrm{Cu}$ and $\mathrm{Fe}$ content must not exceed $3.0 \mathrm{mg} \mathrm{L}^{-1}$ and $5.0 \mathrm{mg} \mathrm{L}^{-1}$, respectively (Tables 1 and 2) in WW for their discharge onto agricultural lands. In consonance, MPL standardized by different agencies/Governments for heavy-metals also revealed wide variation. A MPL value for $\mathrm{Ni}$ in WW between 0.2 to $3.0 \mathrm{mg} \mathrm{L}^{-1}$, for Cd between 0.01 to $2.0 \mathrm{mg} \mathrm{L}^{-1}$, for $\mathrm{Pb}$ between 0.1 to $5.0 \mathrm{mg} \mathrm{L}^{-1}$, for As between 0.1 to 1.0 $\mathrm{mg} \mathrm{L}^{-1}$, for Co between 0.05 to $0.5 \mathrm{mg} \mathrm{L}^{-1}$, for Cr between 0.05 to $2.0 \mathrm{mg} \mathrm{L}^{-1}$ has been standardized (Tables 1 and 2) by different agencies/Governments. Concentration of total suspended solids (TSS) in WW for Irrigation purpose should be $<400 \mathrm{mg} \mathrm{L}^{-1}[16],<300 \mathrm{mg} \mathrm{L}^{-1}$ (Tokyo standards) and $<100 \mathrm{mg} \mathrm{L}^{-1}[19]$.

\subsection{Heavy-metal Content of Waste Water Generated by Different Industries}

Waste waters differed remarkably with respect to their chemical composition depending upon the source from where they are originated[22-41]. Industries use different chemicals depending upon their requirement and purpose of operations and thus generate effluents contaminated with pollutants of different nature and that too in vary concentrations. Even the same type of effluent discharged by two different industrial units varies largely with respect to their chemical composition[26,40]. Effluents of industries when flushed in the sewage drains passing across the industrial areas further exhibit elevated levels of chemical constituents $[12,23,41]$. Effluents from sewage drain contain pollutants in far high concentration than those are orig inally discharged by an industrial unit.

A study conducted at Ludhiana (India) for comparing the heavy-metal composition of different industrial effluents categorized sugar-mills under highly pollution causing category, followed by tannery effluents that contains 9.20-13.8 $\mathrm{mg} \mathrm{Cr} \mathrm{L}^{-1}$, which had detrimental effect on water quality. However, effluents from electroplating industry were rated under highly acid ic ( $\mathrm{pH} \sim 2.13$ ) category, besides high content of $\mathrm{Ni}\left(2.4-52.0 \mathrm{mg} \mathrm{L}^{-1}\right)$, cyanides $(0.4-4.4 \mathrm{mg}$ 
$\left.\mathrm{L}^{-1}\right)$ and $\mathrm{Cr}\left(4.4-20.0 \mathrm{mg} \mathrm{L}^{-1}\right)[42]$. However, high content of $\mathrm{Zn}\left(18.0 \mathrm{mg} \mathrm{L}^{-1}\right)$ in the effluents from cycle manufacturing industry and ferric sulphate in effluents fro $\mathrm{m}$ steel industry at Ludhiana (India)[42]. In an another study, higher $\mathrm{Cd}, \mathrm{Ni}$ and Co contents in WW of sewage dra in passing across industrial area manufacturing metallic products than the effluents discharged directly by textile dye and wool industry have been reported[23]. High $\mathrm{Cd}$ content was observed in effluents of electroplating industry and high $\mathrm{Cr}$ content (140-times higher than MPL) in effluents of leather industry[23]. Steel industry effluents from Esfahan (Iran) contaminated with 0.08 to $0.41 \mathrm{mg} \mathrm{Fe} \mathrm{L}^{-1}, 0.02$ to $0.25 \mathrm{mg}$ $\mathrm{Zn} \mathrm{L}^{-1}, 0.2$ to $0.08 \mathrm{mg} \mathrm{Cu} \mathrm{L}^{-1}, 0.0$ to $0.02 \mathrm{mg} \mathrm{Pb} \mathrm{L}^{-1}, 0.0$ to $0.02 \mathrm{mg} \mathrm{Cd} \mathrm{L} \mathrm{L}^{-1}, 0.0$ to $0.13 \mathrm{mg} \mathrm{Cr} \mathrm{L}{ }^{-1}, 0.0$ to $0.14 \mathrm{mg}$ and 0.0 to $0.042 \mathrm{mg} \mathrm{Ni} \mathrm{L}^{-1}$ has been reported[35]. The comparison of chemical characteristics of effluents fro $m$ different industries in Pakistan elucidates ghee industry effluents as most injurious to soil and plant health, because of its high EC $\left(\sim 8.14 \mathrm{~d} \mathrm{~S} \mathrm{~m}^{-1}\right)$ than effluents from textile, chemical juncture and city sewage[31]. Although, environment protection agencies (Tables 1 and 2) have standardized a cut-off EC limit ( 3.0 to $5.0 \mathrm{dS} \mathrm{m}^{-1}$ ) for effluents fro $\mathrm{m}$ different industries for their disposal in agriculture for crop production, there is report[43] that still discouraged use of WW for sensitive crops, even with EC level of WW within the permissible limits. Considerable variation in heavy-metal concentration in effluents discharged by marble, chemical, textile, steel, dyes and coal industries has also been observed[28]. Mean concentration of $0.19 \mathrm{mg} \mathrm{Zn} \mathrm{L} \mathrm{L}^{-1}, 0.01 \mathrm{mg} \mathrm{Cu} \mathrm{L}^{-1}, 0.07 \mathrm{mg}$ $\mathrm{Mn} \mathrm{L}^{-1}, 0.87 \mathrm{mg} \mathrm{Fe} \mathrm{L}^{-1}, 0.77 \mathrm{mg} \mathrm{Pb} \mathrm{L}^{-1}$ and $0.02 \mathrm{mg} \mathrm{Cd} \mathrm{L}^{-1}$ in municipal WW of Irbid, Jordan has been reported[9]. Leather complex effluents mixed with municipal SW from Ludhiana (India) were reported to contain $0.41 \mathrm{mg} \mathrm{Cu} \mathrm{L}^{-1}$, $20.1 \mathrm{mg} \mathrm{Fe} \mathrm{L}^{-1}, 0.39 \mathrm{mg} \mathrm{Mn} \mathrm{L}^{-1}, 2.25 \mathrm{mg} \mathrm{Zn} \mathrm{L}^{-1}, 4.03 \mathrm{mg} \mathrm{Al}$

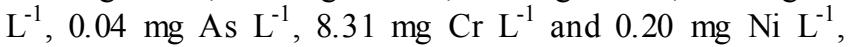
representing 42, 155, 98, 31, 50, 4, 1400 and 52-times, respectively higher heavy-metal content than GW, due to mixing of industrial effluents [23].

Table 1. Maximum permissible level $\left(\mathrm{mg} \mathrm{L}^{-1}\right.$, except for $\mathrm{pH}, \mathrm{SAR}$, for $\mathrm{EC}\left(\mathrm{dS} \mathrm{m}^{-1}\right)$ of different agencies for different parameters for waste waters to be used as irrigation water

\begin{tabular}{|c|c|c|c|c|c|c|c|}
\hline \multirow[b]{2}{*}{ Parameter } & \multicolumn{7}{|c|}{ Reference } \\
\hline & [21] & {$[15]$} & [14] & [20] & [18] & {$[91 / 82]$} & $\begin{array}{c}\text { Pakistan Emission } \\
\text { standards }\end{array}$ \\
\hline $\mathrm{pH}$ & - & - & $6.5-8.4$ & $6.0-10.0$ & $7.0-8.5$ & $6.5-8.5$ & - \\
\hline $\mathrm{EC}$ & -- & -- & $<3$ & 4.0 & 3.0 & 2.25 & -- \\
\hline SAR & - & $6.0-9.0$ & $<9.0$ & -- & -- & -- & -- \\
\hline Hardness & -- & -- & $200-600$ & - & $200-600$ & -- & -- \\
\hline Alkalinity & -- & -- & -- & -- & -- & -- & -- \\
\hline TSS & - & - & - & 150 & - & $200^{\mathrm{c}}$ & $<200$ \\
\hline TDS & - & 1500 & $<450$ & 3500 & - & $500,2100^{\mathrm{c}}$ & - \\
\hline BOD & $<2^{\mathrm{a}},<5^{\mathrm{b}}$ & -- & $28-30$ & 80 & - & $100^{\mathrm{c}}$ & $<80$ \\
\hline $\mathrm{COD}$ & -- & -- & -- & 150 & -- & -- & $<150$ \\
\hline Oil and grease & - & - & -- & 10 & -- & -- & -- \\
\hline Phenolic compounds & -- & -- & -- & - & -- & - & $<0.1$ \\
\hline $\mathrm{TN}$ & -- & -- & $<30.0$ & -- & -- & -- & -- \\
\hline $\mathrm{TP}$ & -- & -- & 8.6 & -- & 5.0 & -- & -- \\
\hline $\mathrm{TK}$ & -- & -- & 34.7 & -- & $75-200$ & -- & -- \\
\hline $\mathrm{N}-\mathrm{NO}_{3}$ & $<5.0$ & -- & $<10$ & -- & 20 & -- & -- \\
\hline $\mathrm{N}-\mathrm{NH}_{4}$ & $<5.0$ & - & 0.2 & - & 0.2 & -- & -- \\
\hline $\mathrm{SO}_{4}^{2-}-\mathrm{S}$ & -- & 500 & $42-45$ & 600 & $42-45$ & -- & -- \\
\hline $\mathrm{Na}$ & -- & 230 & $<70$ & -- & 200 & -- & -- \\
\hline $\mathrm{Mg}$ & -- & 100 & -- & -- & $50-150$ & -- & -- \\
\hline $\mathrm{Ca}$ & -- & 230 & -- & -- & $150-200$ & -- & -- \\
\hline $\mathrm{Mn}$ & -- & 0.2 & 0.2 & 1.5 & 0.5 & 0.1 & $<1.5$ \\
\hline $\mathrm{Zn}$ & - & 5.0 & 2.0 & 5.0 & $<1.0$ & 5.0 & $<5.0$ \\
\hline $\mathrm{Cu}$ & -- & 0.2 & 0.2 & 1.0 & $<1.0$ & 0.05 & $<1.0$ \\
\hline $\mathrm{Fe}$ & -- & 5.0 & 5.0 & 2.0 & -- & 0.3 & -- \\
\hline $\mathrm{Ni}$ & -- & 0.2 & 0.2 & 1.0 & 0.5 & 0.2 & -- \\
\hline $\mathrm{Cd}$ & -- & 0.01 & 0.01 & 0.1 & $<1.0$ & 0.01 & $<1.0$ \\
\hline $\mathrm{Pb}$ & -- & 5.0 & 5.0 & 0.5 & $<1.0$ & 0.1 & $<0.5$ \\
\hline Mo & -- & 0.01 & -- & -- & -- & - & -- \\
\hline As & -- & 0.1 & -- & -- & -- & -- & $<1.0$ \\
\hline Co & -- & -- & 0.05 & -- & -- & 0.05 & -- \\
\hline $\mathrm{Cr}$ & 0.05 & 0.1 & 0.1 & 1.0 & 0.05 & 0.05 & $<1.0$ \\
\hline
\end{tabular}

$\mathrm{a}=$ for crops consumed raw, $\mathrm{b}=$ for processed crops and fodders $\mathrm{c}=$ standards of CPCB (Central Pollution Control Board, New Delhi India), 2001 
Table 2. Maximum permissible level $\left(\mathrm{mg} \mathrm{L}^{-1}\right.$, except for $\mathrm{pH}$ and $\mathrm{EC}\left(\mathrm{dS} \mathrm{m}^{-1}\right)$ of different agencies for different parameters for waste waters to be used as irrigation water

\begin{tabular}{|c|c|c|c|c|c|c|c|c|c|c|c|c|}
\hline \multirow[b]{2}{*}{ Parameter } & \multicolumn{12}{|c|}{ Reference } \\
\hline & $\begin{array}{c}\text { China } \\
\text { [94] }\end{array}$ & $\begin{array}{c}\text { Japan } \\
{[94]}\end{array}$ & $\begin{array}{c}\text { Caribbean } \\
{[94]}\end{array}$ & $\begin{array}{c}\text { Kenya } \\
{[94]}\end{array}$ & $\begin{array}{c}\text { Uganda } \\
\text { [94] }\end{array}$ & $\begin{array}{c}\text { Nigeria } \\
{[94]}\end{array}$ & [19] & [17] & [16] & [91] & $\begin{array}{c}\text { Tokoyo } \\
\text { Standards }\end{array}$ & $\begin{array}{c}\text { Pakistan } \\
\text { Emission } \\
\text { standards }\end{array}$ \\
\hline $\mathrm{pH}$ & $6.0-9.0$ & $6.0-8.5$ & $6.0-9.0$ & $6.9-8.5$ & $6.0-8.0$ & $6.0-9.0$ & $6.0-8.5$ & $6.5-8.5$ & $5.0-9.0$ & $6.5-8.5$ & -- & -- \\
\hline $\mathrm{EC}$ & -- & -- & -- & -- & -- & -- & -- & 3.0 & $3.0-5.0$ & 2.25 & -- & -- \\
\hline SAR & -- & - & -- & -- & -- & -- & -- & 15.0 & 10.0 & -- & - & -- \\
\hline Hardness & -- & -- & -- & -- & -- & -- & -- & -- & -- & -- & -- & -- \\
\hline Alkalinity & -- & -- & -- & -- & -- & -- & -- & -- & -- & -- & -- & -- \\
\hline TSS & -- & -- & -- & -- & -- & -- & 100 & - & 400 & -- & $<300$ & $<200$ \\
\hline TDS & -- & -- & -- & -- & -- & -- & -- & 2000 & 2000 & 500 & -- & -- \\
\hline BOD & -- & - & -- & -- & -- & - & 100 & -- & -- & - & $<300$ & $<80$ \\
\hline COD & -- & -- & -- & -- & -- & -- & 200 & -- & 1500 & -- & - & $<150$ \\
\hline$O \& G$ & -- & -- & -- & -- & -- & -- & -- & - & 150 & - & -- & -- \\
\hline $\begin{array}{l}\text { Phenolic } \\
\text { compounds }\end{array}$ & -- & -- & -- & -- & -- & -- & -- & -- & -- & -- & $<5.0$ & $<0.1$ \\
\hline $\mathrm{TN}$ & -- & -- & -- & -- & -- & -- & -- & -- & 80.0 & -- & $<120$ & -- \\
\hline $\mathrm{TP}$ & -- & -- & -- & -- & -- & -- & -- & -- & 50.0 & -- & -- & -- \\
\hline TK & -- & -- & -- & -- & -- & -- & -- & -- & -- & -- & -- & -- \\
\hline $\mathrm{N}-\mathrm{NO}_{3}$ & -- & -- & -- & -- & -- & -- & -- & -- & -- & -- & -- & -- \\
\hline $\mathrm{N}-\mathrm{NH}_{4}$ & -- & -- & -- & -- & -- & -- & -- & -- & -- & -- & -- & -- \\
\hline $\mathrm{SO}_{4}{ }^{2-}-\mathrm{S}$ & -- & - & - & 1000 & 500 & 500 & - & 21.0 & 1500 & - & - & - \\
\hline $\mathrm{Na}$ & -- & -- & -- & -- & -- & -- & -- & 39.0 & 300 & -- & -- & -- \\
\hline $\mathrm{Mg}$ & -- & -- & -- & -- & -- & -- & -- & -- & -- & -- & -- & -- \\
\hline $\mathrm{Ca}$ & -- & -- & -- & -- & -- & -- & -- & -- & -- & -- & -- & -- \\
\hline $\mathrm{Mn}$ & 10 & 10 & -- & -- & 1.0 & 5.0 & -- & -- & 2.0 & 0.1 & $<10.0$ & $<1.5$ \\
\hline $\mathrm{Zn}$ & -- & -- & -- & -- & -- & -- & 2.0 & -- & 2.0 & 5.0 & $<5.0$ & $<5.0$ \\
\hline $\mathrm{Cu}$ & 3.0 & 1.0 & 3.0 & 1.0 & 1.0 & 1.0 & 0.2 & 0.1 & 2.0 & 0.05 & $<3.0$ & $<1.0$ \\
\hline $\mathrm{Fe}$ & & & & & & & 3.0 & 5.0 & 5.0 & 0.3 & - & -- \\
\hline $\mathrm{Ni}$ & 1.0 & -- & 3.0 & 1.0 & 1.0 & 1.0 & 2.0 & - & 2.0 & 0.2 & -- & -- \\
\hline $\mathrm{Cd}$ & 0.03 & 0.1 & 2.0 & 0.5 & 0.5 & 1.0 & 0.05 & 0.01 & 0.05 & 0.01 & $<0.1$ & $<1.0$ \\
\hline $\mathrm{Pb}$ & -- & 0.1 & 0.1 & 3.0 & 0.1 & 1.0 & 1.0 & 2.0 & 1.0 & 0.1 & $<0.1$ & $<0.5$ \\
\hline Mo & -- & - & -- & -- & -- & -- & -- & -- & -- & -- & -- & -- \\
\hline As & -- & -- & -- & -- & -- & -- & -- & -- & 1.0 & -- & $<0.1$ & $<1.0$ \\
\hline Co & -- & -- & -- & -- & -- & -- & 0.05 & 0.05 & 0.5 & 0.05 & -- & -- \\
\hline $\mathrm{Cr}$ & 2.0 & 0.1 & 2.0 & 1.0 & 1.0 & 1.0 & 1.0 & 0.1 & - & 0.05 & $<0.5$ & $<1.0$ \\
\hline
\end{tabular}

$\mathrm{a}=$ for crops consumed raw, $\mathrm{b}=$ for processed crops and fodders

Tannery effluents from Tamil Nadu (India) were reported to deteriorate the quality by increasing $\mathrm{Cr}$ content fro $\mathrm{m} 9.2$ to $13.8 \mathrm{mg} \mathrm{L}^{-1}$ in surface water (SW) and thereby rendering it unfit for agricultural use[44]. Sugar and distillery effluent discharge in Gelabi river of Assam (India) have been reported to adversely affect the quality of water with respect to $\mathrm{pH}$, total dis solved solids (TDS), dissolved oxygen (DO), biological oxidation demand (BOD), and chemical oxygen demand (COD)[45]. Waste water flushed in 'Budha Nallah' passing in the outskirts of highly industrialized (electroplating, bicycles, dyeing industries) town Ludhiana (India) was reported to contain was 42.2, 2.8, 3.5, 1.67, 35.0, 6.0 and 47.2-times higher $\mathrm{Fe}, \mathrm{Zn}, \mathrm{Cu}, \mathrm{Pb}, \mathrm{Ni}$, $\mathrm{As}$ and $\mathrm{Cr}$ content, respectively than the WW sampled from less industrialized town, Sangrur (Punjab, India)[41], that indicates the substantial heavy-metal contribution of industry. Similarly, the sewage WW carry ing effluents from several industries established across the periphery of Ballabgarh (India), contained appreciably higher content heavy-metals $(\mathrm{Pb}, \mathrm{Ni}$ and $\mathrm{Cd})$ than that the $\mathrm{WW}$ from less industrialized areas[46]. Textile WW from Tamil Nadu (India) has been reported to contain $1500 \mathrm{mg} \mathrm{HCO}_{3} \mathrm{~L}^{-1}, 526$ $\mathrm{mg} \mathrm{Cl} \mathrm{L}{ }^{-1}, 580 \mathrm{mg} \mathrm{Ca} \mathrm{L}^{-1}, 140 \mathrm{mg} \mathrm{Mg} \mathrm{L}{ }^{-1}, 46 \mathrm{mg} \mathrm{Na} \mathrm{L}^{-1}$ and $28.2 \mathrm{mg} \mathrm{K} \mathrm{L}^{-1}$, with alka line $\mathrm{pH}$ (8.1 to 8.9) and highly saline nature $\left(\mathrm{EC}=6.2 \mathrm{dS} \mathrm{m}^{-1}\right)[36]$. In contrast, however, the effluents from pharmaceutical industry in Benin City (Nigeria) were less saline in nature $\left(E C=1.7 \mathrm{dS} \mathrm{m}^{-1}\right)$ and have almost same $\mathrm{pH}(8.38)$, but less $\mathrm{K}\left(139 \mathrm{mg} \mathrm{L}^{-1}\right)$, Ca (343 $\left.\mathrm{mg} \mathrm{L}^{-1}\right)$ and $\mathrm{Mg}\left(51 \mathrm{mg} \mathrm{L}^{-1}\right)[30]$.

Optimu $\mathrm{m}$ range of $\mathrm{pH}$ of the irrigation water from 6.5 to 8.5 has been suggested, while permissible limit 9.0 has been standardized[47]. Treated effluents from El-Sadat City (Egypt) were tested to contain $2.48 \mathrm{mg} \mathrm{Fe} \mathrm{L}^{-1}, 0.95 \mathrm{mg} \mathrm{Mn}$ $\mathrm{L}^{-1}, 0.72 \mathrm{mg} \mathrm{Zn} \mathrm{L}^{-1}, 0.31 \mathrm{mg} \mathrm{Cu} \mathrm{L}^{-1}, 0.27 \mathrm{mg} \mathrm{Ni} \mathrm{L}^{-1}, 0.08 \mathrm{mg}$ Co L $\mathrm{L}^{-1}, 0.06 \mathrm{mg} \mathrm{Cd} \mathrm{L}^{-1}$ and $1.28 \mathrm{mg} \mathrm{Pb} \mathrm{L}^{-1}$ [29]. However, wide variation in properties of effluents discharged by different industries established in Gaborone (Africa) has been reported[24]. The study reports wide variation in $\mathrm{pH} v i z$. fro $\mathrm{m} \mathrm{H}=6.6$ in effluents of bravery to $\mathrm{pH}=9.3$ in effluents from pharmaceutical industry, while near neutral $\mathrm{pH}$ in the effluents from chemical and paint $(\mathrm{pH}=6.92)$ and food and beverages $(\mathrm{pH}=7.02)$ industry. These concentrations thus revealed that WW differed greatly depending upon the industry and nature of chemicals being used. 


\subsection{Other quality Related Parameters of $W$ aste}

There are many other quality related parameters (Tables 1 and 2) that had an important bearing on quality of WW for irrigation purpose. A sewage drain carrying effluents from electroplating, bicycles and dyeing industries of Ludhiana (India) was reported to have higher values of 130 and $245 \mathrm{mg}$ $\mathrm{L}^{-1}$ of BOD and COD respectively against 43.9 and $174 \mathrm{mg}$ $\mathrm{L}^{-1}$ in the sewage WW from less industrialized town, Sangrur, (Punjab, India) indicating high BOD value for $\mathrm{WW}$ of Ludhiana than MPL (100 $\left.\mathrm{mg} \mathrm{L}^{-1}\right)$ of FAO for irrigation[41]. In an another study a wide range in quality parameters viz. $\mathrm{pH}=10$ to $11.5, \mathrm{TSS}=300$ to $500 \mathrm{mg} \mathrm{L^{-1 }}, \mathrm{TDS}=8000$ to 9000 $\mathrm{mg} \mathrm{L} \mathrm{L}^{-1}, \mathrm{BOD}=400$ to $800 \mathrm{mg} \mathrm{L} \mathrm{L}^{-1}, \mathrm{COD}=900$ to $1500 \mathrm{mg} \mathrm{L}^{-1}$, oil and grease $=20$ to $25 \mathrm{mg} \mathrm{L}^{-1}, \mathrm{Cr}=0.24 \mathrm{mg} \mathrm{L}^{-1}$ and sulphide-S=3.64 $\mathrm{mg} \mathrm{L}^{-1}$ has been reported in sewage WW from Rajasthan (India)[48]. A far wide variation in BOD (350 to as high as $2558 \mathrm{mg} \mathrm{L}^{-1}$ ), Suspended solids (112 to as high as $2069 \mathrm{mg} \mathrm{L}^{-1}$ ) and dissolved oxygen (2.37 to $9.0 \mathrm{mg}$ $\mathrm{L}^{-1}$ ) have also been reported earlier[24]. There fore, to ensure protected use of WW, adequate dilution with quality fresh water is required, for sustainability in crop production and environmental protection.

\section{Effect of Long-term Sewage Irrigation on Soil Physico-chemical Properties}

\subsection{Soil pH}

There are different views associated with effects of long-term WW application on soil $\mathrm{pH}$. There are studies[9,30,33,37,49,50], which confirms increase in soil $\mathrm{pH}$ with WW irrigation of soil. A 50-years long-term study on the use of effluents from textile industry revealed 0.4 unit increase in surface soil $\mathrm{pH}$ than the soils irrigated with GW (Table 3)[36]. In a similar long-term study on the use of sewage WW for 50-60 years, 0.5 unit increase in surface soil $\mathrm{pH}$ has been reported[49]. However, fertilizer manufacturing plant effluents when applied to Nigerian soils had resulted in an increase in soil $\mathrm{pH}$ from 7.23 to 7.76[22]. Significant increase of 0.5 units (Table 5) in surface soil irrigated with mixed domestic and industrial effluents from El-Khashab (Egypt) has also been reported[33]. Such effect may be attributed to the high content of basic cations viz. $\mathrm{Na}^{+}, \mathrm{Ca}^{2+}$ and $\mathrm{Mg}^{2+}$ in the WW, which after accumulation in surface soil layer for a long period of time[51], leads to increase soil $\mathrm{pH}$. The increased in soil pH (Table 3 ) has been referred exclusively to the high content of $\mathrm{Ca}^{2+}$ and $\mathrm{Mg}^{2+}$ of pharmaceutical effluents applied to the soil[30].

Table 3. Effect of waste water irrigation on soil fertility parameters

\begin{tabular}{|c|c|c|c|c|c|c|c|}
\hline \multirow{2}{*}{ Location } & \multirow{2}{*}{$\begin{array}{c}\text { Timeperiod } \\
\text { of study }\end{array}$} & \multirow{2}{*}{$\begin{array}{c}\text { Waste Water } \\
\text { Type }\end{array}$} & \multirow{2}{*}{ Parameter } & \multicolumn{2}{|c|}{ Heavy-metal content } & \multirow{2}{*}{$\begin{array}{c}\Delta \\
\text { (T imes) }\end{array}$} & \multirow{2}{*}{ Reference } \\
\hline & & & & WW & GW & & \\
\hline \multirow{5}{*}{$\begin{array}{l}\text { Tamil Nadu, } \\
\text { India }\end{array}$} & \multirow{5}{*}{50 days } & \multirow{5}{*}{$\begin{array}{l}\text { Textile waste } \\
\text { water }\end{array}$} & $\mathrm{pH}$ & 7.92 & 7.85 & 1.00 & \multirow{5}{*}[36]{} \\
\hline & & & $\mathrm{N}\left(\mathrm{kg} \mathrm{ha}^{-1}\right)$ & 118 & 117 & 1.00 & \\
\hline & & & $\mathrm{P}\left(\mathrm{kg} \mathrm{ha}^{-1}\right)$ & 13.45 & 11.10 & 1.21 & \\
\hline & & & $\mathrm{K}\left(\mathrm{kg} \mathrm{ha}^{-1}\right)$ & 56.0 & 55.0 & 1.01 & \\
\hline & & & $\mathrm{OM}(\%)$ & 1.29 & 0.29 & 4.45 & \\
\hline \multirow{7}{*}{$\begin{array}{l}\text { Benin City, } \\
\text { Nigeria }\end{array}$} & \multirow{7}{*}{8 weeks } & \multirow{7}{*}{$\begin{array}{c}\text { Pharma-ceutical } \\
\text { Effluent }\end{array}$} & $\mathrm{pH}$ & 7.15 & 5.98 & 1.20 & \multirow{7}{*}[30]{} \\
\hline & & & $\mathrm{P}\left(\mathrm{kg} \mathrm{ha}^{-1}\right)$ & 6.00 & 3.07 & 1.95 & \\
\hline & & & $\mathrm{K}\left(\mathrm{cmol} \mathrm{kg}^{-1}\right)$ & 0.32 & 0.41 & 0.78 & \\
\hline & & & $\mathrm{OC}(\%)$ & 1.28 & 1.00 & 1.28 & \\
\hline & & & $\mathrm{Ca}\left(\mathrm{cmol} \mathrm{kg}^{-1}\right)$ & 10.06 & 0.07 & 143.7 & \\
\hline & & & $\mathrm{Na}\left(\mathrm{cmol} \mathrm{kg}^{-1}\right)$ & 1.10 & 0.05 & 22.0 & \\
\hline & & & $\mathrm{CEC}\left(\mathrm{cmol} \mathrm{kg}^{-1}\right)$ & 31.58 & 0.61 & 51.8 & \\
\hline \multirow{7}{*}{$\begin{array}{l}\text { Onne, Rivers } \\
\text { State, Nigeria }\end{array}$} & \multirow{8}{*}{--} & \multirow{8}{*}{$\begin{array}{c}\text { Fertilizer plant } \\
\text { Effluents }\end{array}$} & $\mathrm{pH}$ & 7.76 & 7.23 & 1.07 & \multirow{8}{*}[22]{} \\
\hline & & & $\mathrm{N}\left(\mathrm{g} 100 \mathrm{~g}^{-1}\right)$ & 0.54 & 0.09 & 6.0 & \\
\hline & & & $P\left(g 100 g^{-1}\right)$ & 0.29 & 0.21 & 1.38 & \\
\hline & & & $\mathrm{K}\left(\mathrm{g} 100 \mathrm{~g}^{-1}\right)$ & 32.3 & 2.55 & 12.7 & \\
\hline & & & $\mathrm{Ca}\left(\mathrm{g} 100 \mathrm{~g}^{-1}\right)$ & 0.19 & 0.86 & 0.22 & \\
\hline & & & $\mathrm{Na}\left(\mathrm{g} 100 \mathrm{~g}^{-1}\right)$ & 1.50 & 1.20 & 1.25 & \\
\hline & & & $\operatorname{Mg}\left(\mathrm{g} 100 \mathrm{~g}^{-1}\right)$ & 0.98 & 0.68 & 1.44 & \\
\hline \multirow{6}{*}{$\begin{array}{c}\text { El-Khashab, } \\
\text { Egypt }\end{array}$} & & & $\mathrm{pH}$ & 8.4 & 7.9 & 1.06 & \\
\hline & \multirow{5}{*}{--} & Mixed & $\mathrm{TN}\left(\mathrm{mg} \mathrm{kg}^{-1}\right)$ & 2200 & 500 & 4.40 & \multirow{5}{*}[33]{} \\
\hline & & Domestic and & $\mathrm{NH}_{4}-\mathrm{N}\left(\mathrm{mg} \mathrm{kg}^{-1}\right)$ & 51 & 20 & 2.55 & \\
\hline & & Industrial & $\mathrm{NO}_{3}-\mathrm{N}\left(\mathrm{mg} \mathrm{kg}^{-1}\right)$ & 155 & 67.5 & 2.30 & \\
\hline & & Effluents & $\mathrm{P}\left(\mathrm{mg} \mathrm{kg}^{-1}\right)$ & 11.7 & 2.2 & 5.30 & \\
\hline & & & $\mathrm{K}\left(\mathrm{mg} \mathrm{kg}^{-1}\right)$ & 10.2 & 13.3 & 0.77 & \\
\hline \multirow{5}{*}{$\begin{array}{l}\text { Khajura, } \\
\text { Nepal }\end{array}$} & \multirow{5}{*}{--} & & $\mathrm{pH}$ & 6.4 & 7.2 & 0.88 & \\
\hline & & & OM $(\%)$ & 4.07 & 0.52 & 7.83 & \\
\hline & & Distillery & $\mathrm{TN}(\%)$ & 0.17 & 0.10 & 1.70 & [38] \\
\hline & & & $\mathrm{P}_{2} \mathrm{O}_{5}-\mathrm{P}\left(\mathrm{kg} \mathrm{ha}^{-1}\right)$ & 183 & 84 & 2.18 & \\
\hline & & & $\mathrm{K}_{2} \mathrm{O}-\mathrm{K}\left(\mathrm{kgha}^{-1}\right)$ & 590 & 209 & 2.82 & \\
\hline & & & $\mathrm{pH}$ & 7.7 & 7.2 & 1.07 & \\
\hline & & & $\mathrm{OC}(\%)$ & 0.37 & 0.19 & 1.95 & \\
\hline Calcutta, & $50-60$ years & Sewage & $\mathrm{TN}(\%)$ & 0.10 & 0.06 & 1.67 & [49] \\
\hline India & & Effluents & $\mathrm{TP}(\%)$ & 0.10 & 0.05 & 2.00 & \\
\hline & & & TK $(\%)$ & 0.13 & 0.07 & 1.86 & \\
\hline & & & $\mathrm{pH}$ & 8.1 & 8.3 & 0.98 & \\
\hline & & & $\mathrm{OC}(\%)$ & 1.73 & 1.24 & 1.40 & \\
\hline Kurukshetra, & 25 years & Sewage & $\mathrm{TN}(\%)$ & 0.15 & 0.08 & 1.89 & [53] \\
\hline & & & ТP (\%) & 0.88 & 0.56 & 1.57 & \\
\hline & & & TK $(\%)$ & 0.24 & 0.18 & 1.33 & \\
\hline
\end{tabular}


Table 4. Physico-chemical properties of surface $(0-15 \mathrm{~cm})$ soils irrigated with waste water and ground water

\begin{tabular}{|c|c|c|c|c|c|c|}
\hline \multirow[b]{2}{*}{ Source/Reference } & \multicolumn{6}{|c|}{ Soil property } \\
\hline & $\mathrm{pH}(1: 2)$ & $\begin{array}{c}\text { EC }(1: 2), d S \\
m^{-1}\end{array}$ & OC (\%) & $\mathrm{CaCO}_{3}(\%)$ & Clay $(\%)$ & $\begin{array}{c}\text { CEC } \\
\left.\left(\mathrm{cmol} \mathrm{kg}^{-1}\right)\right)\end{array}$ \\
\hline & & & [2] & & & \\
\hline WW & $7.1-8.3$ & 0.42 & 0.95 & 1.5 & 11.3 & 11.16 \\
\hline GW & $7.7-8.5$ & 0.33 & 0.77 & 3.5 & 7.3 & 6.35 \\
\hline WW & 7.95 & 0.89 & 0.83 & -- & -- & -- \\
\hline GW & 7.68 & 0.69 & $\begin{array}{l}0.37 \\
{[33]}\end{array}$ & -- & -- & -- \\
\hline WW & $8.2-8.4$ & $3.15-3.53$ & $1.4-2.2$ & $18.8-19.8$ & $3.8-5.0$ & -- \\
\hline GW & 7.9 & 2.5 & $\begin{array}{l}0.14 \\
{[23]}\end{array}$ & 14.0 & 16.0 & -- \\
\hline WW & 6.6 & 0.64 & 0.41 & -- & -- & -- \\
\hline GW & 6.9 & 0.28 & {$\left[\begin{array}{l}0.32 \\
{[29]}\end{array}\right.$} & -- & -- & -- \\
\hline WW & 8.36 & 0.92 & -- & 2.08 & 1.0 & 12.8 \\
\hline GW & 7.87 & 1.12 & {$[30]^{--}$} & 2.11 & 1.0 & 12.6 \\
\hline WW & 7.15 & -- & 1.28 & -- & 9.0 & 42.1 \\
\hline GW & 5.98 & -- & 1.00 & -- & 9.0 & 4.25 \\
\hline
\end{tabular}

Table 5. Available (DTPA) micro-nutrient and heavy-metal concentration $\left(\mathrm{mg} \mathrm{kg}^{-1}\right)$ in surface $(0-15 \mathrm{~cm})$ soils with waste water irrigation $(\mathrm{WWI})$ in comparison to ground water irrigated(GWI) soils

\begin{tabular}{|c|c|c|c|c|c|c|c|}
\hline \multirow{2}{*}{ Location } & \multirow{2}{*}{$\begin{array}{c}\text { Years of } \\
\text { study }\end{array}$} & \multirow{2}{*}{$\begin{array}{c}\text { Waste Water } \\
\text { Type }\end{array}$} & \multirow{2}{*}{ Heavy-metal } & \multicolumn{2}{|c|}{ Heavy-metal content } & \multirow{2}{*}{$\Delta$ over GW (Times) } & \multirow{2}{*}{ Reference } \\
\hline & & & & WWI & GWI & & \\
\hline \multirow{7}{*}{ Esfahan, Iran } & \multirow{7}{*}{--} & \multirow{7}{*}{ Steel industry } & $\mathrm{Fe}$ & 22.8 & 4.02 & 5.67 & \multirow{7}{*}[35]{} \\
\hline & & & $\mathrm{Cu}$ & 2.67 & 1.07 & 2.50 & \\
\hline & & & $\mathrm{Mn}$ & 15.4 & 9.90 & 1.56 & \\
\hline & & & $\mathrm{Zn}$ & 5.10 & 1.83 & 2.79 & \\
\hline & & & $\mathrm{Cd}$ & 0.42 & 0.12 & 3.50 & \\
\hline & & & $\mathrm{Pb}$ & 4.48 & 1.76 & 2.55 & \\
\hline & & & $\mathrm{Fe}$ & 77.5 & 112.5 & 0.69 & \\
\hline Onne, Rivers & \multirow{4}{*}{--} & \multirow{3}{*}{ Fertilizer plant } & $\mathrm{Zn}$ & 0.93 & 1.91 & 1.02 & \multirow{3}{*}[22]{} \\
\hline \multirow{3}{*}{ State, Nigeria } & & & $\mathrm{Cd}$ & 0.11 & 0.05 & 2.20 & \\
\hline & & & $\mathrm{Pb}$ & 0.50 & 0.65 & 0.77 & \\
\hline & & & $\mathrm{Zn}$ & 187.3 & 94.7 & 1.98 & \multirow{4}{*}[70]{} \\
\hline \multirow{4}{*}{ Tehran, Iran } & \multirow{4}{*}{7} & \multirow{4}{*}{$\begin{array}{l}\text { Domestic and } \\
\text { Industrial }\end{array}$} & $\mathrm{Pb}$ & 78.4 & 50.0 & 1.57 & \\
\hline & & & $\mathrm{Cr}$ & 82.8 & 34.7 & 2.39 & \\
\hline & & & $\mathrm{Ni}$ & 46.0 & 27.4 & 1.68 & \\
\hline & & & $\mathrm{Cu}$ & 4.2 & 0.99 & 4.24 & \\
\hline \multirow{7}{*}{ Ludhiana, India } & & \multirow{7}{*}{$\begin{array}{l}\text { Mixed leather } \\
\text { effluents with } \\
\text { sewage } \\
\text { effluents }\end{array}$} & $\mathrm{Fe}$ & 39.7 & 13.8 & 2.88 & \multirow{7}{*}{ [93] } \\
\hline & & & $\mathrm{Mn}$ & 18.9 & 14.3 & 1.32 & \\
\hline & & & $\mathrm{Zn}$ & 14.7 & 2.9 & 5.07 & \\
\hline & -- & & $\mathrm{Al}$ & 6.5 & 3.63 & 1.79 & \\
\hline & & & As & 2.1 & 1.87 & 1.12 & \\
\hline & & & $\mathrm{Cr}$ & 1.7 & 0.81 & 2.10 & \\
\hline & & & $\mathrm{Ni}$ & 1.27 & 0.56 & 2.27 & \\
\hline & & & $\mathrm{Zn}$ & 187.3 & 94.7 & 1.98 & \\
\hline Tohron Imp & 7 & Municipal & $\mathrm{Pb}$ & 78.4 & 50.0 & 1.57 & \\
\hline Ienran, Iran & 1 & Effluent & $\mathrm{Cr}$ & 82.8 & 34.7 & 2.39 & [37] \\
\hline & & & $\mathrm{Ni}$ & 46.0 & 27.4 & 1.68 & \\
\hline & & & $\mathrm{Zn}$ & 308 & 3.6 & 85.6 & \\
\hline & & & $\mathrm{Cu}$ & 37.1 & 2.4 & 15.46 & \\
\hline & & & $\mathrm{Fe}$ & 143 & 56.6 & 2.53 & \\
\hline & & & $\mathrm{Mn}$ & 27.9 & 22.4 & 1.25 & \\
\hline Kolkata, India & $50-60$ & Sewage & $\mathrm{Cd}$ & 5.2 & 0.01 & 520 & {$[85]$} \\
\hline & & & $\mathrm{Pb}$ & 4.2 & 4.3 & 0.98 & \\
\hline & & & Co & 1.6 & 0.9 & 1.78 & \\
\hline & & & $\mathrm{Ni}$ & 9.0 & 4.2 & 2.14 & \\
\hline & & & $\mathrm{Cr}$ & 15.9 & 3.1 & 5.13 & \\
\hline & & & $\mathrm{Zn}$ & 2.65 & 0.99 & 2.68 & \\
\hline & & & $\mathrm{Cu}$ & 2.06 & 1.45 & 1.42 & \\
\hline & & & $\mathrm{Fe}$ & 22.7 & 17.8 & 1.28 & \\
\hline & & & $\mathrm{Mn}$ & 7.2 & 5.8 & 1.24 & \\
\hline & & Sewage & $\mathrm{Pb}$ & 1.65 & 0.99 & 1.67 & \\
\hline Kurukshetra, India & 25 & effluents & $\mathrm{Ni}$ & 3.3 & 2.4 & 1.38 & [53] \\
\hline & & & $\mathrm{Cr}$ & 6.8 & 2.2 & 3.09 & \\
\hline & & & $\mathrm{Cu}$ & 17.0 & 15.5 & 1.10 & \\
\hline & & & $\mathrm{Pb}$ & 16.5 & 11.0 & 1.50 & \\
\hline & & & $\mathrm{Cd}$ & 40.5 & 26.5 & 1.53 & \\
\hline
\end{tabular}


On the contrary, there are studies [52-54] which confirms the decrease in surface soil $\mathrm{pH}$ with $\mathrm{WW}$ irrigation to soils. A 20-years long-term experimentation on the use of sewage WW for irrigating crops revealed decrease in soil $\mathrm{pH}$ by 0.4 units over initial $\mathrm{pH}$ value[54]. Similar results showed of decrease in soil $\mathrm{pH}$ with WW irrigation in different soils of varying agro-climatic conditions have also been reported $[52,53]$. Decrease in soil $\mathrm{pH}$ with distillery effluents [38], industrial effluents [55] and steel industry effluents[42] has also been documented. The decrease in soil $\mathrm{pH}$ with $\mathrm{WW}$ application might be the result of oxidation of different organic compounds and nitrification of ammonia[56]. Production of organic acids due to anaerobic decomposition of organic matter[57] has been attributed as principal cause for reduced $\mathrm{pH}$ with $\mathrm{WW}$ irrigation[12].

However, no significant difference in $\mathrm{pH}$ o f soils fro marid climate zone, irrigated with municipal effluents for 16-months than from potable irrigation has been reported [58]. Statistical non-significant differences in soil $\mathrm{pH}$ with WW over GW irrigation $[9,36]$ have also been reported.

\subsection{Electrical Conductivity (EC) and Related Parameters}

Significantly maximum EC value of soil irrigated with municipal WW application consecutively for 10-years has been reported[9]. Remarkably higher accumulation of soluble salts in the deeper soil layers $(20-40$ and $40-60 \mathrm{~cm})$ than surface $(0-20 \mathrm{~cm})$ soil layer has been ascribed to the leaching effect with irrigate water[9]. Significant increase in surface soil EC with WW application[37] in contrast to significant decrease in EC of soil, with the application of industrial effluents in rice culture areas of Pakistan[55] has been reported. A study in the arid climate on the use of municipal effluents in soils for 16-months recapitulated increased $\mathrm{EC}$ value by $0.5 \mathrm{dS} \mathrm{m}^{-1}, \mathrm{Na}^{+}$by $6.0 \mathrm{mmol} \mathrm{L}^{-1}$ and the exchangeable sodium percentage (ESP) by 6.8[58]. However, soil $\mathrm{Ca}^{2+}+\mathrm{Mg}^{2+}$ concentrations were greater in soils irrigated with industrial effluent by $0.5 \mathrm{mmol} \mathrm{L}^{-1}$ but were lesser when compared with potable irrigation. Leachate collected at $61 \mathrm{cmdepth}$ indicated that effluent irrigated soil leachate were higher than potable water irrigated leachate primarily in EC by $0.2 \mathrm{~d} \mathrm{~S} \mathrm{~m}^{-1}$ and $\mathrm{Na}^{+}$content by $0.8 \mathrm{mmol}$ $\mathrm{L}^{-1}[58]$. However, study with a short-term (2 years) application of sewage WW to the calcareous soils of Spain, there was a slight increase in $\mathrm{EC}$ and $\mathrm{Na}^{+}$concentration in soils the than soils irrigated with GW[50]. In a potato culture in soils of Jalandhar (Punjab, India), an increase in soil EC from 0.28 to $0.64 \mathrm{dS} \mathrm{m}^{-1}$ has been reported with the use of municipal WW contaminated by leather complex effluents [23]. Remarkable increase in sodium adsorption ratio (SAR) of soils receiving industrial effluents has been reported[55]. Increased EC of surface soil with WW application in comparison to GW irrigated soils (Table 8) has also been reported in many other studies conducted in different agro-climatic conditions $[9,23,29,30,33]$. The increased salt concentration of soil receiving $\mathrm{WW}$ on regular basis has been referred to the orig inal level of TDS of WW[56].

\subsection{Soil Organic Carbon}

Soil organic carbon (OC) has been the exclusive indicator of soil quality as it acts as a store of plant available nutrients [54]. Long-term use of WW for irrigation to crops results in significant increased in soil OC than the soils irrigated with $\mathrm{GW}[9,12,23,30,36-38,52,54,56,59]$. In sub-tropical Indian soils, an increase of $38-79 \%$ in soil OC content with 20-years of sewage WW irrigation as compared to GW irrigated soils has been reported[54]. However, in Vertisols of Mexico City there was an increased in soil OC content by 2.5 -fold after 80 -years of SW irrigation over GW irrigated soil[60]. After 36-years of domestic sewage effluent irrigation, significant improvement in the soil OM from $1.24-1.78 \%$, especially down to a distance of one $\mathrm{Km}$ along the disposal channel, has been reported[53]. Even after 8-weeks of pharmaceutical effluent application@ @ 75,000 L $\mathrm{ha}^{-1}$ to Nigerian soils, there was an increase in soil OC from 1.00 to $1.08 \%$ (Table 5)[30]. About 7.8-fold increase in soil organic matter (OM) content (from 0.52-4.07\%) with distillery effluent application in soils of Nepal has been reported[38]. Sewage WW irrigation for 50-60 years in soils of Calcutta (India) has exh ibited an increase in soil OC from 0.19 to $0.37 \%[49]$ and from 1.24 to $1.73 \%$ after 25 years (Table 7) in soils of Kurukshetra (Haryana, India)[53]. Large additions of OM from sewage WW and anaerobic conditions developed due to heavy loading of OM had reduced OC (Table 3 and 4) decomposition and have resulted in build-up of soil OC[12]. Therefore, long-term WW irrigation can be a good means of carbon sequestration in soil and can thus be referred as a soil quality sustaining practice.

\subsection{Calcium Carbonate}

In Egypt, considerable increase in calcium carbonate $\left(\mathrm{CaCO}_{3}\right)$ content of surface soil receiving $\mathrm{WW}$ for irrigation, in comparison to soils receiving $\mathrm{GW}$ has been reported (Table 4)[33]. In an another area of Egypt, however 1.42\% decrease in surface soil $\mathrm{CaCO}_{3}$ content was reported with the use of WW for irrigation purpose over GW irrigated soils (Table 4)[29]. The significant reduction in $\mathrm{CaCO}_{3}$ content of soil with sewage WW irrigation $[12,61]$ may be the result of decrease in soil $\mathrm{pH}$ and production of organic acids [57] as a result of anaerobic decomposition of OM, wh ich had lead to the solublization of $\mathrm{CaCO}_{3}$ and thereafter it's leaching below the root zone[61].

\subsection{Soil Macro-nutrients}

Reports from different studies on soil fertility parameters and indicated a spectacular change in all measured parameters with WW irrigation (Table 3). Improvement in soil fertility with WW irrigation over a period of time has been well documented[9,30,33,38,49,53]. After 10-years of municipal WW application, significant increase in soil available $\mathrm{N}, \mathrm{P}$ and $\mathrm{K}$ content in surface $(0-20 \mathrm{~cm})$ soil has 
been reported[9]. In 36-years long-term experiment on the use of domestic sewage WW, the build-up of $2908 \mathrm{~kg}$ TN $\mathrm{ha}^{-1}, 58 \mathrm{~kg}$ Av-P ha ${ }^{-1}, 2115 \mathrm{~kg}$ TP ha ${ }^{-1}, 305 \mathrm{~kg} \mathrm{Av-K} \mathrm{ha}{ }^{-1}$ and $4712 \mathrm{~kg} \mathrm{TK} \mathrm{ha}^{-1}$ in surface soil has als o been reported[9]. Even the used of municipal WW in soils of arid climate for 16-months has resulted in increase in $\mathrm{NO}_{3}-\mathrm{N}$ content by 7.8 $\mathrm{mg} \mathrm{kg}{ }^{-1}$, TP by $31.7 \mathrm{mg} \mathrm{kg}^{-1}$ and TK by $134 \mathrm{mg} \mathrm{kg}^{-1}$ [58]. Likewise, TN, TP and TK content in soils irrigated with sewage WW were 2200, 2000 and $25940 \mathrm{mg} \mathrm{kg}^{-1}$ as against 1141,1120 and $14600 \mathrm{mg} \mathrm{kg}^{-1}$ in GW irrigated soils has been reported[49]. Likewise, 440-times increase in $\mathrm{TN}$ content (from 500-2200 mg kg-1), 5.3-times increase in Av-P (from 2.2-11.7 mg kg ${ }^{-1}$ ) and 2.55-times increase in $\mathrm{NH}_{4}-\mathrm{N}$ content (from 20-51 mg kg-1) (Table 3) has also been reported[58]. The fertigation/ manural value of WW for crop production in different agro-climatic conditions has been well documented $[6-8,13]$. Earlier research in India had substantiated maximum yield of onion with maximum fertilizer use efficiency (FUE) with the application of 25-times diluted distillery waste along with $100 \%$ recommended NPK dose [62].

\section{Effect of Waste Water Irrigation on DTPA-extractable Micro-nutrient and Heavy-metal Content}

Waste water contains micro-nutrients and heavy-metals in appreciable amounts[9,23,26,29,30,35,38,39,46,63], but there are many pros and cons associated with their availability to plants. There are studies that have shown the build-up of mic ro-nutrients and heavy-metals in the soils to a varying extent (Table 5 and 6)[41,54,59,64] after repeated use of WW for irrigation to crops. Elevated levels of different heavy-metals in soils irrigated regularly with WW have also been reported[37,66]. Significant increase in DTPA-extractable $\mathrm{Pb}$ and $\mathrm{Cd}$ upto $30 \mathrm{~cm}$ soil layer with the application of WW, consecutively for 80 -years than the soils irrigated with GW has been reported[66]. The plough (0-15 $\mathrm{cm})$ layer of soils of highly industrialized city of Ludhiana (Punjab, India) irrigated largely with sewage effluents are reported to contain $4.21,3.58,0.30,11.9,25.4$ and $49.2 \mathrm{mg}$ $\mathrm{L}^{-1}$ DTPA-extractable $\mathrm{Pb}, \mathrm{Ni}, \mathrm{Cd} \mathrm{Zn}, \mathrm{Mn}$ and $\mathrm{Fe}$ were as compared to $2.76,0.40,0.12,2.10,8.34,10.88 \mathrm{mg} \mathrm{L}^{-1}$ in the less industrialized city of Sangrur (Punjab, India) indicating maximum loading of soils of Ludhiana with heavy-metals through sewage irrigation[41]. Likewise sandy soils irrigated with WW are reported to contain $3.2,122,129,186,22.0$, 14.5 and 10.5-fold higher concentrations of DTPA-Fe, Mn, $\mathrm{Zn}, \mathrm{Cu}, \mathrm{Co}$ and $\mathrm{Ni}$, respectively than soils receiving $\mathrm{GW}$ as irrigation (Table 6). A study conducted at three sites in Harare (Zimbabwe) to investigate the magnitude of contamination, and annual loadings of soils with $\mathrm{Cu}, \mathrm{Zn}, \mathrm{Cd}$, $\mathrm{Ni}, \mathrm{Cr}$ and $\mathrm{Pb}$ where $\mathrm{WW}$ irrigation was practiced in vegetable gardens for 10-years, reports that heavy-metal concentrations in sandy and sandy-clay soils ranged from
7.0 to $145 \mathrm{mg} \mathrm{kg}^{-1}$ for $\mathrm{Cu}, 14$ to $228 \mathrm{mg} \mathrm{kg}^{-1}$ for $\mathrm{Zn}, 0.5$ to $3.4 \mathrm{mg} \mathrm{kg}^{-1}$ for $\mathrm{Cd},<0.01$ to $21 \mathrm{mg} \mathrm{kg}^{-1}$ for $\mathrm{Ni}, 33$ to 225 $\mathrm{mg} \mathrm{kg}^{-1}$ for $\mathrm{Cr}$ and 4 to $59 \mathrm{mg} \mathrm{kg}^{-1}$ for $\mathrm{Pb}$ upto $20 \mathrm{~cm}$ soil depths[64]. The annual heavy-metal loading rates showed that within 5-60 years, all studied heavy-metals would have exceeded their permitted limits in soils, depending on site[64].

In the van region of Turkey, the volcanic soils are reported to contain 2 to 50 -fold higher concentration of $\mathrm{Cd}, \mathrm{Pb}, \mathrm{Cu}$ and $\mathrm{Co}, \sim 40$-fold higher $\mathrm{Zn}$ concentration with the application of WW over GW irrigated soils. A metal enrich ment factor of $\mathrm{Cd}$ (1.8), $\mathrm{Cr}$ (1.7), $\mathrm{Cu}$ (2.3), $\mathrm{Zn} \mathrm{(2.0),} \mathrm{Pb}$ (1.9) and the metal contamination factor of $\mathrm{Cd}$ (2.6), $\mathrm{Cr}$ (1.5), $\mathrm{Cu}$ (2.0), $\mathrm{Zn} \mathrm{(1.7),} \mathrm{Pb}$ (1.6) in soil that showed the accumulation of toxic metals during the SW irrigation has been reported[65]. The study had reported homogeneous distribution of these heavy-metals in WW irrigation area, but with s mall-scale heterogeneous spatial distribution.

Sewage WW irrigation for consecutive 20-years has resulted in significant build-up of DTPA-extractable $\mathrm{Zn}$ (208\%), $\mathrm{Cu}(170 \%), \mathrm{Fe}(170 \%)$, Ni (63\%) and $\mathrm{Pb}(29 \%)$ in soils over GW irrigated soils, whereas Mn content was depleted by $31 \%[54]$. Fractionation study indicated relatively higher build-up of $\mathrm{Zn}, \mathrm{Cu}, \mathrm{Fe}$ and $\mathrm{Mn}$ in bio-availab le pools of sewage WW irrigated soils, which had bearing on crop production and produce quality. In contrast, however non-significant differences in soil available $\mathrm{Pb}$ and Cd content in soils of Jordan with the application of municipal WW even up to 10 -years has also been reported. Likewise, inconsistent variation in heavy-metal content of soil with industrial WW application has also been reported[56].

\subsection{Effect of Waste Water Irrigation on Total Heavy-metal Content of Soil}

Spectacular increase in total heavy-metal content of surface soil layer with WW application has been documented (Table 7). Large addition of heavy-metals through repeated WW irrigation of soils have made these differences in comparis on to control/soils irrigated with GW (Table 5 and 6). A long-term study on the use of sewage WW in soils of Calcutta (India) reported 2.43, 46.5, 3.81, 0.86, 93.0, 15.9, 3.88, 2.44 and 6.61-fold increase in total-Fe, $\mathrm{Zn}, \mathrm{Cu}, \mathrm{Mn}, \mathrm{Cd}$, $\mathrm{Pb}, \mathrm{Co}, \mathrm{Ni}$ and $\mathrm{Cr}$ concentration in comparison to soils receiving GW for irrigating the crops (Table 7)[49]. A considerable build-up of $1241 \mathrm{mg} \mathrm{Fe} \mathrm{kg}{ }^{-1}, 208 \mathrm{mg} \mathrm{Zn} \mathrm{kg}{ }^{-1}$, $37 \mathrm{mg} \mathrm{Cu} \mathrm{kg}{ }^{-1}, 53 \mathrm{mg} \mathrm{Mn} \mathrm{kg}{ }^{-1}, 3.1 \mathrm{mg} \mathrm{Cd} \mathrm{kg}{ }^{-1}, 54 \mathrm{mg} \mathrm{Ni} \mathrm{kg}{ }^{-1}$ and $56 \mathrm{mg} \mathrm{Cr} \mathrm{kg}^{-1}$ in surface soil layer with WW irrigation over GW irrigation has been reported[68]. The accumulation of heavy-metals in the surface soil layers may be the result of sorption reactions of negatively charged soil colloids for these cationic heavy-metals.

\subsection{Effect of Waste Water Irrigation on Profile Distribution of Heavy-metals}

Heavy-metals being extremely immobile and persistent in 
environment and of non-biodegradable in nature, tended to accumulate mainly in the surface soil layer and their content decreased down the profile[23,37,55,69,70]. Table 8 report data on profile distribution and accumulation of heavy-meta ls from different studies, revealed their surface (upto $15 \mathrm{~cm}$ layer) build-up than in the sub-surface soil layers.

After a 36-years long-term use of domestic sewage WW for irrigation, there was an accumulation of heavy-metals in surface $(0-30 \mathrm{~cm})$ soil layers[53]. Likewise, a study in Vertisols irrigated for over 50-years with an un-treated municipal WW, reported elevated levels of DTPA-extractable $\mathrm{Cd}, \mathrm{Co}$, and $\mathrm{Ni}$ in the cultivated layer $(0-15 \mathrm{~cm})$ of the soil as compared to lower layers [71]. The long-term in-situ accumulation of $\mathrm{Cr}$ and $\mathrm{Ni}$ in the soil profile of a large-scale effluent recharge after 24-years of
WW in the Coastal Plain of Israel has also been reported[72]. The effluent recharge led to measurable accumulation, relative to the pristine soil, of $\mathrm{Ni}$ in the 0 to $400 \mathrm{~cm}$ soil profile, with concentration increases of 0.3 to $1.3 \mathrm{mg} \mathrm{kg}$. Chromium concentration increased by 3.1 to $7.3 \mathrm{mg} \mathrm{kg}^{-1}$ in the zero to $100 \mathrm{~cm}$ horizon and 0.9 to $2.3 \mathrm{mg} \mathrm{kg}^{-1}$ at deeper horizons. In an another study, a significant accumulation of $\mathrm{Pb}$ within top $0-15 \mathrm{~cm}$ soil layer as a consequence of $100 \%$ WW treated soils, in contrast to $\mathrm{Ni}, \mathrm{Co}$ and $\mathrm{Cr}$ that remained relative ly uniform throughout the soil profile with mean $(n=6)$ concentration of $30.0 \mathrm{mg} \mathrm{Ni} \mathrm{kg}{ }^{-1}, 12.3 \mathrm{mg} \mathrm{Co} \mathrm{kg}-1$ and 56.3 $\mathrm{mg} \mathrm{Cr} \mathrm{kg}{ }^{-1}$ soil has been reported (Table 8)[73]. Infect, the vertical distribution of heavy-metals due to WW irrigation has been reported to vary from element to element and soil texture (Table 8)[23].

Table 6. Available (DTPA) micro-nutrient and heavy-metal concentration $\left(\mathrm{mg} \mathrm{kg}^{-1}\right)$ in surface $(0-15 \mathrm{~cm})$ soils with waste water irrigation (WWI) in comparison to ground water irrigated(GWI) soils

\begin{tabular}{|c|c|c|c|c|c|c|c|}
\hline \multirow[b]{2}{*}{ Location } & \multirow{2}{*}{$\begin{array}{c}\text { Years of } \\
\text { study }\end{array}$} & \multirow{2}{*}{$\begin{array}{c}\text { WasteWater } \\
\text { Type }\end{array}$} & \multirow{2}{*}{ Heavy-metal } & \multicolumn{2}{|c|}{ Heavy-metal content } & \multirow{2}{*}{$\begin{array}{l}\Delta \text { over GW } \\
\text { (T imes) }\end{array}$} & \multirow[b]{2}{*}{ Reference } \\
\hline & & & & WWI & GWI & & \\
\hline \multirow{8}{*}{ Faridabad, India } & \multirow{8}{*}{20} & \multirow{8}{*}{$\begin{array}{l}\text { Industrial } \\
\text { effluent }\end{array}$} & $\mathrm{Zn}$ & 96 & 68 & 1.41 & \multirow{8}{*}{ [68] } \\
\hline & & & $\mathrm{Cu}$ & 43 & 23 & 1.87 & \\
\hline & & & $\mathrm{Fe}$ & 69 & 41 & 1.68 & \\
\hline & & & $\mathrm{Mn}$ & 8.2 & 4.0 & 2.05 & \\
\hline & & & $\mathrm{Cd}$ & 1.1 & 0.3 & 3.67 & \\
\hline & & & $\mathrm{Pb}$ & 61 & 29 & 2.10 & \\
\hline & & & $\mathrm{Ni}$ & 3.6 & 2.4 & 1.50 & \\
\hline & & & $\mathrm{Cr}$ & 7.5 & 3.3 & 2.27 & \\
\hline \multirow{4}{*}{ Ludhiana, India } & \multirow{4}{*}{--} & \multirow{4}{*}{ Sewage water } & $\mathrm{Pb}$ & 7.12 & 3.88 & 1.84 & \multirow{4}{*}[12]{} \\
\hline & & & $\mathrm{Cr}$ & 0.71 & 0.02 & 35.5 & \\
\hline & & & $\mathrm{Cd}$ & 0.18 & 0.05 & 3.60 & \\
\hline & & & $\mathrm{Ni}$ & 14.3 & 1.00 & 14.3 & \\
\hline \multirow{7}{*}{ El-Sadat City, Egypt } & \multirow{7}{*}{5} & \multirow{7}{*}{ Industrail water } & $\mathrm{Fe}$ & 5.05 & 1.58 & 3.20 & \multirow{7}{*}{ [29] } \\
\hline & & & $\mathrm{Mn}$ & 3.67 & 0.03 & 122.3 & \\
\hline & & & $\mathrm{Zn}$ & 2.57 & 0.02 & 128.5 & \\
\hline & & & $\mathrm{Cu}$ & 1.85 & 0.01 & 185.0 & \\
\hline & & & Co & 0.22 & 0.01 & 22.0 & \\
\hline & & & $\mathrm{Ni}$ & 0.29 & 0.02 & 14.5 & \\
\hline & & & $\mathrm{Pb}$ & 0.42 & 0.04 & 10.5 & \\
\hline \multirow{8}{*}{$\begin{array}{c}\text { El-Khashab, } \\
\text { Egypt }\end{array}$} & \multirow{8}{*}{--} & \multirow{8}{*}{$\begin{array}{l}\text { Mixed Domestic } \\
\text { and Industrial } \\
\text { Effluents }\end{array}$} & $\mathrm{Fe}$ & 78.4 & 2.8 & 28.0 & \multirow{8}{*}{ [33] } \\
\hline & & & Mn & 29.4 & 8.7 & 3.38 & \\
\hline & & & $\mathrm{Zn}$ & 22.2 & 3.4 & 6.53 & \\
\hline & & & $\mathrm{Cu}$ & 6.3 & 2.8 & 2.25 & \\
\hline & & & Co & 0.18 & 0.09 & 2.00 & \\
\hline & & & $\mathrm{Ni}$ & 14.1 & 0.63 & 22.4 & \\
\hline & & & $\mathrm{Pb}$ & 7.95 & 2.3 & 3.46 & \\
\hline & & & $\mathrm{Cd}$ & 0.19 & 0.03 & 6.33 & \\
\hline \multirow{4}{*}{ Khajura, Nepal } & \multirow{4}{*}{--} & \multirow{4}{*}{$\begin{array}{l}\text { Distillery } \\
\text { Effluents }\end{array}$} & $\mathrm{Mn}$ & 419 & 320 & 1.31 & \\
\hline & & & $\mathrm{Cu}$ & 17.0 & 15.5 & 1.10 & \\
\hline & & & $\mathrm{Pb}$ & 16.5 & 11.0 & 1.50 & [38] \\
\hline & & & $\mathrm{Cd}$ & 40.5 & 26.5 & 1.53 & \\
\hline & & & $\mathrm{Zn}$ & 21.4 & 3.6 & 5.94 & \\
\hline & & & $\mathrm{Cu}$ & 18.1 & 5.1 & 3.55 & \\
\hline & & & $\mathrm{Fe}$ & 29.8 & 8.6 & 3.47 & \\
\hline Malerkot la, India & -- & Sewage & $\mathrm{Mn}$ & 11.8 & 9.9 & 1.19 & {$[90]$} \\
\hline & & & $\mathrm{Pb}$ & 5.1 & 1.5 & 3.4 & \\
\hline & & & $\mathrm{Ni}$ & 1.3 & 0.08 & 16.3 & \\
\hline
\end{tabular}


Table 7. Total micro-nutrient and heavy-metal concentration $\left(\mathrm{mg} \mathrm{kg}^{-1}\right)$ in surface $(0-15 \mathrm{~cm})$ soils with waste water irrigation (WWI) in comparison to ground water irrigated (GWI) soils

\begin{tabular}{|c|c|c|c|c|c|c|c|}
\hline \multirow{2}{*}{ Location } & \multirow{2}{*}{$\begin{array}{c}\text { Years of } \\
\text { study }\end{array}$} & \multirow{2}{*}{$\begin{array}{l}\text { WasteWater } \\
\text { Type }\end{array}$} & \multirow{2}{*}{ Heavy-metal } & \multicolumn{2}{|c|}{ Heavy-metal content } & \multirow{2}{*}{$\Delta$ over GW (Times) } & \multirow{2}{*}{ Reference } \\
\hline & & & & WWI & GWI & & \\
\hline \multirow{11}{*}{$\begin{array}{c}\text { Kolkata, } \\
\text { India }\end{array}$} & \multirow{11}{*}{$50-60$} & \multirow{11}{*}{$\begin{array}{l}\text { Sewage } \\
\text { effluents }\end{array}$} & $\mathrm{Fe}$ & 22120 & 9090 & 2.43 & \multirow{11}{*}{ [49] } \\
\hline & & & $\mathrm{Zn}$ & 1210 & 26 & 46.5 & \\
\hline & & & $\mathrm{Cu}$ & 198 & 52 & 3.81 & \\
\hline & & & $\mathrm{Mn}$ & 382 & 446 & 0.86 & \\
\hline & & & $\mathrm{Cd}$ & 3.72 & 0.04 & 93.0 & \\
\hline & & & $\mathrm{Pb}$ & 385 & 24.2 & 15.9 & \\
\hline & & & Co & 46.6 & 12.0 & 3.88 & \\
\hline & & & $\mathrm{Ni}$ & 61.0 & 25 & 2.44 & \\
\hline & & & $\mathrm{Cr}$ & 164 & 24.8 & 6.61 & \\
\hline & & & $\mathrm{Cu}$ & $1.8-6.3$ & 1.15 & $1.57-5.48$ & \\
\hline & & & $\mathrm{Cd}$ & $0.12-0.20$ & 0.15 & $0.80-1.33$ & \\
\hline \multirow{7}{*}{$\begin{array}{l}\text { Faridabad, } \\
\text { India }\end{array}$} & \multirow{7}{*}{20} & \multirow{7}{*}{ Sewage water } & $\mathrm{Fe}$ & 2207 & 966 & 2.28 & \multirow{7}{*}{ [68] } \\
\hline & & & $\mathrm{Zn}$ & 261 & 53 & 4.92 & \\
\hline & & & $\mathrm{Cu}$ & 60 & 23 & 2.61 & \\
\hline & & & $\mathrm{Mn}$ & 241 & 188 & 1.28 & \\
\hline & & & $\mathrm{Cd}$ & 4.2 & 1.1 & 3.82 & \\
\hline & & & $\mathrm{Ni}$ & 73 & 19 & 3.84 & \\
\hline & & & $\mathrm{Cr}$ & 79 & 23 & 3.43 & \\
\hline \multirow{7}{*}{$\begin{array}{l}\text { El-Sadat, } \\
\text { City, Egypt }\end{array}$} & \multirow{7}{*}{5} & \multirow{7}{*}{ Industrial water } & $\mathrm{Fe}$ & 52.9 & 30.8 & 1.72 & \multirow{7}{*}{ [29] } \\
\hline & & & $\mathrm{Mn}$ & 26.3 & 10.6 & 2.48 & \\
\hline & & & $\mathrm{Zn}$ & 11.5 & 4.23 & 2.72 & \\
\hline & & & $\mathrm{Cu}$ & 6.96 & 1.55 & 4.49 & \\
\hline & & & Co & 1.91 & 0.45 & 4.24 & \\
\hline & & & $\mathrm{Ni}$ & 1.88 & 0.99 & 1.90 & \\
\hline & & & $\mathrm{Pb}$ & 6.82 & 2.89 & 2.36 & \\
\hline
\end{tabular}

Values less than 1.0 represent a decrease in heavy-metal content

Values represent concentration in upper $(0-5 \mathrm{~cm})$ soil layer

Table 8 Vertical distribution of heavy-metals in soil at varying depths in relation to type of irrigation water

\begin{tabular}{|c|c|c|c|c|c|}
\hline \multirow{2}{*}{ Location/Reference } & \multirow{2}{*}{ Type } & \multicolumn{4}{|c|}{ Concentration of heavy-metals $\left(\mathrm{mg} \mathrm{kg}^{-1}\right)$ at varying depths } \\
\hline & & $\mathrm{Pb}$ & As & $\mathrm{Ni}$ & $\mathrm{Cr}$ \\
\hline \multirow{4}{*}{$\begin{array}{l}\text { Haroonabad and Faislabad, } \\
\text { Pakistan[73] }\end{array}$} & WW & $\begin{array}{l}10.4(0-15 \mathrm{~cm}) \\
9.2(15-90 \mathrm{~cm})\end{array}$ & -- & $30.2(0-90 \mathrm{~cm})$ & $56.0(0-90 \mathrm{~cm})$ \\
\hline & Conjunctive use & $\begin{array}{l}13.4(0-5 \mathrm{~cm}), \\
6.4(5-90 \mathrm{~cm})\end{array}$ & -- & $26.9(0-90 \mathrm{~cm})$ & $46.5(0-90 \mathrm{~cm})$ \\
\hline & GW & $7.9(0-90 \mathrm{~cm})$ & -- & $22.5(0-90 \mathrm{~cm})$ & $64.2(0-90 \mathrm{~cm})$ \\
\hline & EEC-MPL ${ }^{*}$ & $50-300$ & -- & $30-75$ & $100-150$ \\
\hline \multirow{3}{*}{ Tehran, Iran[70] } & $\begin{array}{c}\text { WW } \\
\text { (7-years) }\end{array}$ & $\begin{array}{l}78.4(0-15 \mathrm{~cm}) \\
53.0(15-30 \mathrm{~cm})\end{array}$ & -- & $\begin{array}{l}46.0(0-15 \mathrm{~cm}) \\
36.4(15-30 \mathrm{~cm})\end{array}$ & $\begin{array}{l}82.5(0-15 \mathrm{~cm}) \\
61.3(15-30 \mathrm{~cm})\end{array}$ \\
\hline & GW & $\begin{array}{l}50.0(0-15 \mathrm{~cm}) \\
23.0(15-30 \mathrm{~cm})\end{array}$ & -- & $\begin{array}{l}27.4(0-15 \mathrm{~cm}) \\
20.2(15-30 \mathrm{~cm})\end{array}$ & $\begin{array}{l}34.7(0-15 \mathrm{~cm}) \\
27.2(15-30 \mathrm{~cm})\end{array}$ \\
\hline & FAO-MPL $^{* *}$ & 50 & -- & 30 & 100 \\
\hline Tehran, Iran[37] & $\begin{array}{c}\text { WW } \\
\text { (7-years use) } \\
\text { GW }\end{array}$ & $\begin{array}{l}78.4(0-15 \mathrm{~cm}), \\
53.0(15-30 \mathrm{~cm}), \\
42.1(30-60 \mathrm{~cm}) \\
50.0(0-15 \mathrm{~cm}), \\
23.0(15-30 \mathrm{~cm}), \\
18.72(30-60 \mathrm{~cm})\end{array}$ & -- & $\begin{array}{c}46.0(0-15 \mathrm{~cm}), \\
36.4(15-30 \mathrm{~cm}), \\
28.3(30-60 \mathrm{~cm}) \\
27.4(0-15 \mathrm{~cm}), 20.2 \\
(15-30 \mathrm{~cm}), 13.3 \\
(30-60 \mathrm{~cm})\end{array}$ & $\begin{array}{c}82.8(0-15 \mathrm{~cm}), 61.3 \\
(15-30 \mathrm{~cm}), 43.3 \\
(30-60 \mathrm{~cm}) \\
34.7(0-15 \mathrm{~cm}), 27.2 \\
(15-30 \mathrm{~cm}), 20.1 \\
(30-60 \mathrm{~cm})\end{array}$ \\
\hline Jalandhar, India[23] & GW & (20) & $\begin{array}{c}1.87(0-15 \mathrm{~cm}), 1.72 \\
(15-30 \mathrm{~cm}), 2.10 \\
(30-45 \mathrm{~cm}), 2.20 \\
(45-60 \mathrm{~cm}) \\
2.09(0-15 \mathrm{~cm}), 2.01 \\
(15-30 \mathrm{~cm}), 1.67 \\
(30-45 \mathrm{~cm}), 2.23 \\
(45-60 \mathrm{~cm})\end{array}$ & $\begin{array}{c}0.56(0-15 \mathrm{~cm}), 0.49 \\
(15-30 \mathrm{~cm}), 0.42 \\
(30-45 \mathrm{~cm}), 0.39 \\
(45-60 \mathrm{~cm}) \\
1.27(0-15 \mathrm{~cm}), 0.91 \\
(15-30 \mathrm{~cm}), 0.78 \\
(30-45 \mathrm{~cm}), 0.69 \\
(45-60 \mathrm{~cm})\end{array}$ & $\begin{array}{c}0.81(0-15 \mathrm{~cm}), 0.48 \\
(15-30 \mathrm{~cm}), 0.59 \\
(30-45 \mathrm{~cm}), 0.44 \\
(45-60 \mathrm{~cm}) \\
1.72(0-15 \mathrm{~cm}), 1.07 \\
(15-30 \mathrm{~cm}), 0.64 \\
(30-45 \mathrm{~cm}), 0.39 \\
(45-60 \mathrm{~cm})\end{array}$ \\
\hline
\end{tabular}


Table 9. Heavy-metal concentration $\left(\mathrm{m} \mathrm{kg}^{-1}\right)$ in crop plants with waste water irrigation (WWI) in comparison to control

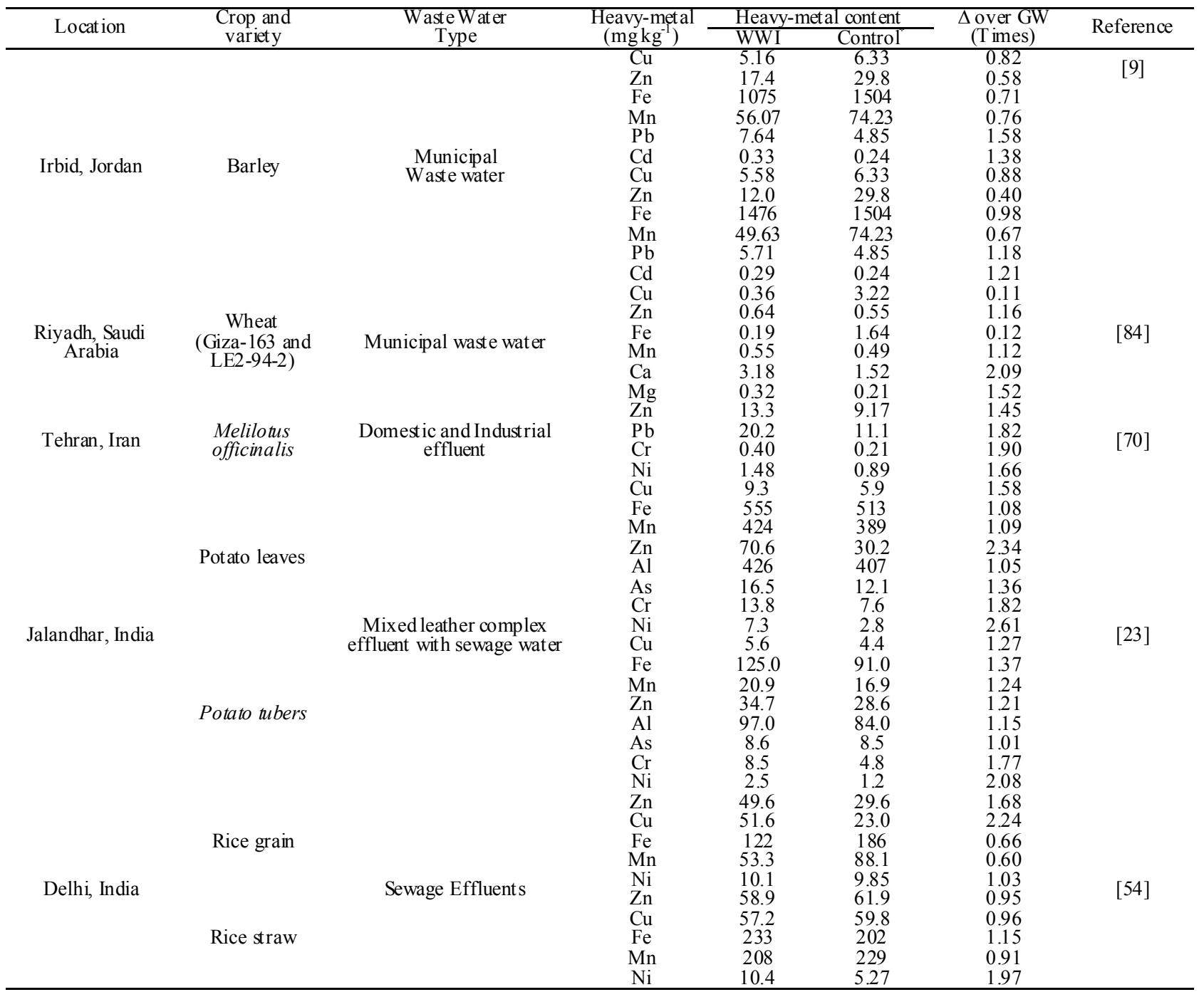

* Control represents either the content at start of study or the content in GW irrigated soil

\section{Effect of Waste Water Irrigation on Yield and Quality}

\subsection{Crop Yield}

Waste waters contain valuable plant nutrients and thus its reuse in agriculture serves as an important source of nutrients and irrigation water for crops. Better crop growth particularly of leafy vegetable like cauliflower, cabbage, spinach etc. grown on fields receiving sewage $\mathrm{WW}$ have been achieved[74], in contrast to radish, which is more sensitive to $\mathrm{WW}[75]$. The results of many studies on the use of WW for long period of time have recapitulated significant increased in crop yields than GW irrigated fields. Significantly higher onion y ield and maximum fertilizer use efficiency from plots fertilized with $40 \mathrm{~kg} \mathrm{~N}, 20 \mathrm{~kg} \mathrm{P}_{2} \mathrm{O}_{5}$ and $20 \mathrm{~kg} \mathrm{~K} \mathrm{~K}_{2} \mathrm{O} \mathrm{ha}{ }^{-1}$ dose conjointly with distillery effluents (25-times diluted) over GW irrigated plots has been reported [62]. A significant augmentation (3.38 $\mathrm{g} \mathrm{pot}^{-1}$ to $\left.8.85 \mathrm{~g} \mathrm{pot}^{-1}\right)$ in dry matter yield of barseem (Trifoliam sp.) in pots irrigated with sewage WW than GW irrigated pots[76] signifies the essential nutrient supplementation from WW. The field experiments conducted on the use of WW for irrigation to maize, sunflower, groundnut and soybean registered 19.3, 29.9, 5.9 and 4.8\% higher grain yield, respectively over fields irrigated with GW (Table 9)[77].

A favourable effect of treated paper and pulp industry effluents on maize, barley and wheat grown in coarse textured soil has also been reported in India[78]. The yield increase from 6.9 to $13.9 \%$ in different sugarcane varieties grown with WW over GW irrigation has been recorded[77]. Likewise, a significant increase in barley biomass with municipal WW irrigation application consecutively for 5 -years over control, in contrast to lower barley biomass from fields irrigated with WW for cons ecutively for 10-years has been reported[9]. The study has shown that barley biomass was still higher over control, albeit of decline in biomass after 5-years of field application[9]. An another long-term experiment have shown that sewage WW irrigation had lead to highest grain yield of wheat, rice and 
cotton by 23, 46 and 50\% than GW irrigation[79]. A gradual increase in peanut pod yield has also been reported with the application of WW upto $50 \%$ concentration in effluent from textile industry[36].

On the contrary, however, yield suppressing trends ( $40 \%$ yield decline) with distillery effluent irrigation fields has also been reported[38]. Average productivity of rice and wheat fro $\mathrm{m}$ fields irrigated with fresh GW to around $48.1 \mathrm{q} \mathrm{ha}^{-1}$ and $8.37 \mathrm{q} \mathrm{ha}^{-1}$ in comparis on to fields irrigated with distillery effluents to 27.8 and $6.89 \mathrm{q} \mathrm{ha}^{-1}$, respectively has been reported[38].

\subsection{Heavy-metal Content}

Plant species differed widely (Table 9 and 10) with respect to their bio-accumulation of heavy-metals and micro-nutrients [80-84]. Heavy-metal and micro-nutrients content in the economic plant parts have been found to be higher[85]. Spinach has been found to accumulation higher amount of $\mathrm{Pb}, \mathrm{Cr}$ and $\mathrm{Cd}$ compared to Trifolium alexandrinum L[12]. Root crops such as potato, carrot, turnip, and radish generally accumulates lower concentrations of pollutant elements than leafy vegetables such as spinach, methi (Trigonella cornuculata), menthe (Triginella foenumgraecum) and mint (Mentha piprita)[81]. Higher concentrations of $\mathrm{Zn}$ and $\mathrm{Cu}$, slight increase in $\mathrm{Ni}$ content and lower concentration of $\mathrm{Mn}$ in rice grains harvested from sewage WW irrigated fields have been registered than GW irrigated fields[54]. However, the tis sue metal concentrations in some cereals, millet and vegetable crops grown in peri-urban areas of Delhi (India) were well below the generalized critical levels of phytotoxicity [54].

Heavy-metal accumulation in leaves of different plant species grown on soils irrigated with industrial WW for consecutive 5-years followed the order: jojoba $>$ khaya $>$ axodium $>$ Italian cypress[29]. In Zimbabwe, maize and Tsunga grown with sewage $\mathrm{WW}$ irrigation were observed to be heavily contaminated with $\mathrm{Cd}, \mathrm{Cu}, \mathrm{Pb}$ and $\mathrm{Zn}[86]$. Tsunga leaves contained $3.68 \mathrm{mg} \mathrm{Cd} \mathrm{kg}{ }^{-1}$, over 18-times the MPL of EU standards $\left(0.2 \mathrm{mg} \mathrm{kg}^{-1}\right) ; \mathrm{Cu}$ concentrations were $111 \mathrm{mg} \mathrm{kg}^{-1}$, 5-times the EU Standard $\left(20 \mathrm{mg} \mathrm{kg}^{-1}\right)$; concentrations of $\mathrm{Pb}$ were $6.77 \mathrm{mg} \mathrm{kg}^{-1}$, over 22-times the MPL of EU standards and UK guidelines $\left(0.3 \mathrm{mg} \mathrm{kg}^{-1}\right) ; \mathrm{Zn}$ concentrations were $221 \mathrm{mg} \mathrm{kg}^{-1}$, over 4-times the guideline value $\left(50 \mathrm{mg} \mathrm{kg}^{-1}\right)$. They reported that the other plants viz. beans, maize, peppers and sugarcane also contained concentrations of heavy-metals above the MPL of EU standards [86]. The edible portion of Beta vulgaris (Palak)-a highly nutritious leafy vegetable in the sub-urban areas of Varanasi (India) has been reported to contain $\mathrm{Cd}$ in higher concentration during the summer seas on than the MPL of the Indian standard, whereas $\mathrm{Pb}$ and $\mathrm{Ni}$ concentrations were higher in summer and winter seasons [69]. The fruit and vegetable samples were found to contain 3.5- to 340-fold higher amounts of the heavy-metals $(\mathrm{Co}, \mathrm{Cd}, \mathrm{Pb}, \mathrm{Mn}, \mathrm{Ni}$ and $\mathrm{Cu}$ ) from soils irrigated with $\mathrm{WW}$ than irrigated with GW [67]. In an another study in peri-urban areas of Delhi (India), higher $\mathrm{Zn}, \mathrm{Pb}$ and $\mathrm{Cd}$ levels except $\mathrm{Cu}$ than the
WHO limits in spinach and okra irrigated with industrial effluents has been reported[87]. Vegetables grown on un-contaminated soils contains $8.1-17 \mathrm{mg} \mathrm{Cu} \mathrm{kg}{ }^{-1}, 4.3-7.3$ $\mathrm{mg} \mathrm{Pb} \mathrm{kg}{ }^{-1}$, 44.7-85.5 $\mathrm{mg} \mathrm{Zn} \mathrm{kg}^{-1}$, and $109.2 \mathrm{mg} \mathrm{Mn} \mathrm{kg}{ }^{-1}$, than grown in contaminated soils that contains $9.0-36.5 \mathrm{mg}$ $\mathrm{Cu} \mathrm{kg}{ }^{-1}, 8.5-30.2 \mathrm{mg} \mathrm{Pb} \mathrm{kg}{ }^{-1}, 48.1-181 \mathrm{mg} \mathrm{Zn} \mathrm{kg}^{-1}$ and 109.1-183.0 mg Mn kg ${ }^{-1}$ [4]. The study on the use of sewage $\mathrm{WW}$ for irrigation on the uptake and translocation of $\mathrm{Hg}$ in maize from soils irrigated historically with sewage effluent, and one irrigated solely with GW revealed that $\mathrm{Hg}$ content in roots was positively correlated with soil $\mathrm{Hg}$ content $(r=0.95)$ and the transfer coefficients between roots and stems were significantly higher in the control site[88]. The concentration of $\mathrm{Pb}, \mathrm{Cr}$ and $\mathrm{Ni}$ has been reported to exceed their permissible levels in roots of yellow sweet clover Melilotus officinalis irrigated with WW[70].

Significantly higher heavy-metals accumulation in spinach than okra fruit has been observed[89]. The heavy-metal content in these crops followed the order sewage $\mathrm{WW}>$ mixed sewage $\mathrm{WW}$ and $\mathrm{GW}>\mathrm{GW}[89]$. In general however, heavy-metal accumulation and absorption by plants grown in contaminated environment followed the order of magnitude of greater availability in the surrounding med iu $\mathrm{m}[80,83]$. Direct significant re lationships between soil heavy-metal content and heavy-metal uptake by plants and concentration of heavy-metals in plants showed direct significant relationship with heavy-metal concentration in the waste effluents[12].

Even the different plant parts of same specie differed appreciably from one-another in their ability for absorption, translocation and accumulation of heavy-metals and micro-nutrients[82,90] (Table 10). Rice cultivated with industrial WW in Pakistan, retained $\mathrm{Cu}$ absorbed from soils mainly in the straw and translocates a very minute a mount of it to the grains [55]. In comparis on, $\mathrm{Cd}$ concentration in straw ( 0.135 to $0.370 \mathrm{mg} \mathrm{kg}^{-1}$ ) and grains ( 0.116 to $\left.0.370 \mathrm{mg} \mathrm{kg}^{-1}\right)$ of rice grown at three different locations remained nearly the same[55]. Higher tendency of cauliflower curds to accumulate $\mathrm{Zn}, \mathrm{Cu}, \mathrm{Fe}, \mathrm{Mn}, \mathrm{Pb}$ and $\mathrm{Ni}$ than cauliflower leaves has been reported[90]. The concentration of elements in cauliflower leaves was $39.5,4.1,149,33.7,0.97$ and 1.1 $\mathrm{mg} \mathrm{kg}^{-1}$ in sewage WW irrigated soils than 31.6, 3.6, 101, $29.9,1.28$ and $0.57 \mathrm{mg} \mathrm{kg}^{-1}$ in GW irrigated soils. However, the concentration of these heavy-metals in cau liflower curds was $49,2.9,149.4,22.6,1.87$ and $1.93 \mathrm{mg} \mathrm{kg}^{-1}$, respectively in sewage WW irrigated soils and 39.3, 4.4, 114.4, 19.8, 1.47 and $1.03 \mathrm{mg} \mathrm{kg}^{-1}$, respectively in GW irrigated soils[90]. In Eichhhornia, the mobility of $\mathrm{Ca}, \mathrm{Zn}$ and $\mathrm{Cu}$ remained restricted, while $\mathrm{Mn}, \mathrm{Pb}, \mathrm{Cr}, \mathrm{Ni}$ and $\mathrm{Cd}$ were easily translocated from lower to upper plant parts[90]. Higher concentration of heavy-metals in potato leaves (non-edible portion) than tubers (edible portion) as a result of WW irrigation of light textured soils of Punjab (India) has been reported[23]. The absorption of $\mathrm{Cr}$ and $\mathrm{Ni}$ by potato plants and their distribution in edible and non-edible portions of plant was, however proportional to its build-up in soil[23]. 
Table 10. Heavy-metal concentration $\left(\mathrm{m} \mathrm{kg}^{-1}\right)$ in crop plants with long-term (21-years) sewage waste water irrigation(WWI) in comparison to control[54]

\begin{tabular}{|c|c|c|c|c|}
\hline \multirow{2}{*}{ Crop and variety } & \multirow{2}{*}{$\begin{array}{l}\text { Heavy-metal } \\
\left(\mathrm{mgkg}^{-1}\right)\end{array}$} & \multicolumn{2}{|c|}{ Heavy-metal content } & \multirow{2}{*}{$\begin{array}{l}\text { Per cent increase over } \\
\text { Control }\end{array}$} \\
\hline & & WWI & Control & \\
\hline \multirow{5}{*}{ Wheat } & $\mathrm{Zn}$ & 65.3 & 47.5 & 1.37 \\
\hline & $\mathrm{Cu}$ & 9.39 & 7.45 & 1.26 \\
\hline & $\mathrm{Fe}$ & 404 & 336 & 1.20 \\
\hline & $\mathrm{Mn}$ & 15.3 & 13.6 & 1.13 \\
\hline & $\mathrm{Ni}$ & 20.0 & 19.7 & 1.02 \\
\hline \multirow{5}{*}{ Sorghum } & $\mathrm{Zn}$ & 54.2 & 73.4 & 0.74 \\
\hline & $\mathrm{Cu}$ & 16.9 & 115.5 & 0.15 \\
\hline & $\mathrm{Fe}$ & 526 & 485 & 1.08 \\
\hline & $\mathrm{Mn}$ & 40.6 & 44.8 & 0.91 \\
\hline & $\mathrm{Ni}$ & 14.8 & 11.6 & 1.28 \\
\hline \multirow{5}{*}{ Maize } & $\mathrm{Zn}$ & 78.8 & 67.6 & 1.17 \\
\hline & $\mathrm{Cu}$ & 14.9 & 13.3 & 1.12 \\
\hline & $\mathrm{Fe}$ & 531 & 99.0 & 5.36 \\
\hline & $\mathrm{Mn}$ & 26.0 & 15.3 & 1.70 \\
\hline & $\mathrm{Ni}$ & 16.5 & 5.20 & 3.17 \\
\hline \multirow{5}{*}{ Oats } & $\mathrm{Zn}$ & 59.0 & 44.3 & 1.33 \\
\hline & $\mathrm{Cu}$ & 8.71 & 6.35 & 1.37 \\
\hline & $\mathrm{Fe}$ & 458 & 400 & 1.15 \\
\hline & $\mathrm{Mn}$ & 23.8 & 29.2 & 0.82 \\
\hline & $\mathrm{Ni}$ & 18.3 & 37.3 & 0.49 \\
\hline \multirow{5}{*}{ Gobhi sarson (Brassica napus) } & $\mathrm{Zn}$ & 66.9 & 38.7 & 1.73 \\
\hline & $\mathrm{Cu}$ & 23.1 & 14.1 & 1.64 \\
\hline & $\mathrm{Fe}$ & 454 & 401 & 1.13 \\
\hline & $\mathrm{Mn}$ & 69.0 & 104 & 0.66 \\
\hline & $\mathrm{Ni}$ & 12.0 & 3.73 & 3.22 \\
\hline \multirow{5}{*}{ Spinach } & $\mathrm{Zn}$ & 77.1 & 38.4 & 2.01 \\
\hline & $\mathrm{Cu}$ & 20.6 & 16.1 & 1.28 \\
\hline & $\mathrm{Fe}$ & 711 & 734 & 0.97 \\
\hline & $\mathrm{Mn}$ & 39.3 & 87.8 & 0.45 \\
\hline & $\mathrm{Ni}$ & 18.4 & 13.2 & 1.39 \\
\hline
\end{tabular}

\section{Conclusions}

1. Based on literature thus reviewed, it can be concluded that some industrial effluents hold great promise for the improvement of soil fertility and crop yields, if proper treatment and management practices are adopted.

2. Literature confirms that the WW can effectively increase water resource for irrigation but there is a need for regular monitoring of the heavy-metal and other pollution related parameter concentrations in soil, plants and ground water.

3. Since WW are rich source of micro-nutrients and heavy-metals, the repeated application of WW may accumulate appreciable quantities of heavy-metals and micro-nutrients in the soil. Therefore, such fields need periodic estimates to monitor the build-up of these nutrients.

4. Literature reviewed reveled that safe utilization of WW for irrigation to crops requires several precautionary measures viz. adequate dilution, selection of crop etc. Besides, soil physical properties needs to be reviewed periodically for long-term sustainability of the system.

5. Based on the literature, thus reviewed, it can be concluded that proper management of WW irrigation and periodic monitoring of soil, WW and crop quality are required to ensure success ful, safe and long-term use of WW for irrigation.

6. It is desirable that highly contaminated WW from some industries is made to undergo suitable treatment in WW treatment plants, before its use for irrigation purpose.

\section{REFERENCES}

[1] R. A. Buchholz, Principles of environmental management. The Greetings of Business. $2^{\text {nd }}$ Prentice-Hall, London, U.K., 1998.

[2] Fakayode, S.O., 2005, Impact of industrial effluents on water quality of the receiving Alaro River in Ibadan, Nigeria, Ajeam-Ragee, 10, 1-13.

[3] S. K. Ghimire, Evaluation of industrial effluents toxicity in seed germination and seedling growth of some vegetables, M.Sc. Dissertation, Central Department of Botany (1994), Tribhuvan University, Kirtipur, Kathmandu, Nepal, 1994.

[4] Cheraghi, M., Lorestani, B., Yousefi, N., 2009, Effect of waste water on heavy metal accumulation in Hamedan Province Vegetables., International J. Bot., 5, 190-193.

[5] Singh, K. P., Mohon, D., Sinha, S., Dalwani, R., 2004 Impact assessment of treated/untreated wastewater toxicants discharge by sewage treatment plant on health, agricultural and environmental quality in waste water disposal area., Chemosphere 55, 227-255.

[6] Campbell C. A., and Davidson H. R., 1983, Effect of temperature, nitrogen fertilization and moisture stress use by Manitou spring wheat, Can. J. Plant Sci., 59, 603-626.

[7] Burns, J. C., Westerman, P., King, L. D., Cummings, G. A., Overcash, M. R., Goode, L., Swine lagoon effluents applied to coastal Bermuda grass: 1 . Forage yield, quality and element 
removal, Journal of Environmental Quality 14 (1985), 9-14.

[8] Chaw, R., and Reves, A. S., 2001, Effect of waste water on Menthe piperita and Spinaceal oleraceae., J. Environ. Biol., 51, 131-145.

[9] Rusan, M. J. M., Hinnawi, S., Rousan, L., 2007, Long term effect of waste water irrigation of forage crops on soil and plant quality parameters., Desalinization 215, 143-152.

[10] M. Strauss, and U. J. Blumenthal, Human waste use in agriculture and aquiculture: utilization practices and health perspectives. IRCWD Rep ort 09/90. International Reference Centre for waste Disposal (IRCWD), Duebendorf, Germany, 1990, p. 48.

[11] P. S. Minhas, J. S. Samra, Wastewater use in peri-urban agriculture impacts and opportunities. Technical Bulletin 02/2004. Central Soil Salinity Research Institute (CSSRI), Karnal-132 001, Hary ana, India, 2004.

[12] Dheri, G. S., Brar, M. S., Malhi, S. S., 2007, Heavy-metal concentration of sewage-contaminated water and its impact on underground water, soil and crop plants in Alluvial soils of Northwestern India., Communication in Soil Sci. \& Plant Anal. 38, 1353-1370.

[13] R. Chhabra, Sewage water, utilization through forestry. National Printers, Old Market, West Patel Nagar, New Delhi, India (1989), p: 1-9.

[14] FAO (Food and Agriculture Organization), Soil survey investigations for irrigation. Soil Bull.-42, Rome (R. G. Feachem, 1983 ed.) Sanitation and disease-health aspects of excreta and waste water management. John Wiley \& Sons, Chic Ester, England, 1976.

[15] Government of Jordan, Technical Regulations for Reclaimed Domestic Waste Water JS893/2002, Jordan Institution for Standards and Meteorology, Amman, Jordan, 2003.

[16] Gazette of Mauritius Standards for discharge of industrial effluents into a waste water system, Regulations-2004, Mauritius, 2004.

[17] EPA/ROC, Final reports of heavy metals contents in Taiwan agricultural soils. Vol.-4 Taiwan, ROC, 1989.

[18] WHO (World Health Organization), Guidelines for water quality. Health and other supporting information. WHO, Geneva (1984) 2, p.100.

[19] IEPO, Iranian Environmental Protection Organization, The standards for discharging effluent water. The Research Deputy of Iranian Environmental Protection Organization, 1994.

[20] NEQS, National Environmental Quality Standards: Gazette of Pakistan, Extra-ordinary, Environmental and Urban Affairs Division, Pakistan Environmental Protection Agency: Islamabad, Pakistan, 1993.

[21] E. Agreda, The problematic of the use of polluted water in agriculture under irrigation-Case study Rocha River-La Mayca and Caramarca areas, M.Sc. Thesis, Wageningen University, The Netherlands, 2000.

[22] Ana, G. R. E. E. ., and Sridhar, M. K. C., 2002, Soil quality near a chemical fertilizer industry at Port Harcourt, Nigeria, AJAM/RAGEE 4, 50-57.

[23] Brar, M. S., Khurana, M. P. S., and Kansal, B. D., 2002, Effect of irrigation by untreated sewage effluents on the micro and potentially toxic elements in soils and plants. In Proc $17^{\text {th }}$ World Congress of Soil Science held at Bangkok, Thailand from August 14-21, 2002, Volume-IV, Symposium no.-24, 2002, p. 198(1)-198(6).

[24] Emongor, V., Nkegbe, E., Kealotswe, B., Koorapetse, I., Sankwasa, S., Keikanetswe, S., 2005, Pollution indicators in Gaborone Industrial effluents, J. Applied Sci. 5, 147-150.

[25] Phiri, O., Mumba, P., Moyo, B. H. Z., Kadewa, W., 2005 Assessment of the impact of industrial effluents on water quality of receiving rivers in urban areas of Malawi., International J. Science \& Technology 2, 237-244.

[26] Hargopal-Singh, Dhanwinder-Singh, Singh, K. G., and Pritpal-Singh, Recycling potential of sludge produced by Coca-cola bottling plants in Agriculture. Annual progress report (2005-06), Department of Soils, Punjab Agricultural University-Ludhiana, Punjab, India, 2006.

[27] Verma, V. K., Gupta, R. K., and Rai, J. P. N., 2005, Biosorption of $\mathrm{Pb}$ and $\mathrm{Zn}$ from pulp and paper industry effluent by water hyacinth (Eichhornia crassipes)., J. Scientific \& Ind. Res., 64, 778-781.

[28] Nasrullah, R., Naz, H., Bibi, M., Iqbal, M., and Ily as-Durrani, 2006, Polluted land in industrial effluent and ground water of gadoon Amazai industrial estate (GAIE) SWABI, NWFP., J. Agri.\& Biol. Sci.,3, 18-24.

[29] El-Arby, A. M., and Elbordiny, M .M., 2006, Impact of reused wastewater for irrigation on availability of heavy metals in sandy soils and their uptake by plants., J. Applied Sci. Res., 2, 106-111.

[30] Osaigbovo, A., Ulamen, O., and Ehi-Robert, 2006, Influence of pharmaceutical effluent on some soil chemical properties and early growth of maize (Zea mays L)., African J. Biotech., 5, 612-617.

[31] Sial, R. A., Chaudhary, M. F., Abbas, S. T., Latif, M. I., and Khan, A. G., 2006, Quality of Effluents from Hattar Industrial Estate., J. Zhejiang Uni. Sci., 7, 974-980.

[32] Z. A. Zakria, Z. Zakria, S. Surif, W. A. Ahmad, Bioremediation of $\mathrm{Cr}$ (VI)-containing electroplating waste water using Acinetobacter sp.. Paper Presented in International Conference on Environment (ICENV-2006). November-2006, Penang, Malaysia, 2006.

[33] El-Hady, B. A. A., 2007, Compare the effect of polluted and river Nile irrigation water on contents of heavy-metals of some soils and plants, Res. J. Agri. \& Biol., 3, 287-294.

[34] Pandey, S. K., Tyagi, P., and Gupta, A. K., 2007, Physico-chemical analysis and effect of distillery effluent on seed germination of wheat (Triticum aestivum), pea (Pisum sativum) and lady's finger (Abelmoschu esculentus)., ARPN J. Agric. \& Biol. Sci., 2, 35-40.

[35] Rahmani, H. R., and Rezaer, R., 2007, Effect of industrial effluents of Zob-Han on soil, water and vegetable plants., J. Applied Sci., 17, 2519-2522.

[36] Saravanamoorthy, M. D., and Ranjitha-Kumari, B. D., 2007, Effect of textile water on morphology and yield on two varieties of peanut (Arachis hypogea L.)., J. Agric. Tech., 3, 335-343.

[37] Aghabarati, A., Hosseini, S. M., and Maralian, H., 2008, Heavy metal concentration of soil and olive trees (Olea 
europaea L.) in Suburban areas of Tehran, Iran., Res. J. Environ. Sci., 2, 323-329.

[38] Ale, R., Jha, P. K., and Belbase, N., 2008, Effects of distillery effluents on some agricultural crops: A case of environmental injustice to local farmers in Khajura VDC, Banke., Scientific World, 6, 68-75.

[39] Nagajyoti, P. C., Dinakar, N., Prasad, T. N. V. K. V., Suresh, C., and Damodharam, T., 2008, Heavy metal toxicity: Industrial effect on Groundnut (Arachis hypogaea L.) seedlings, J. Applied Sci. Res., 4, 110-121.

[40] Akan, J. C., Moses, E. A., Ogugbuaja, V. O., and Abah, J., 2007, Assessment of tannery industrial effluents from Kano metropolis, Kano State, Nigeria., J. Applied Sci., 7, 1788-2793.

[41] M. P. S. Khurana, V. K. Nayyar, R. L. Bansal, and M. V. Singh, Heavy metal pollution in soils and plants through untreated sewage water. In: V.P. Singh, R.N. Yadava, (eds.) Ground Water Pollution. Proceedings of the International conference on Water and Environment (WE-2003), Bhopal. Allied Publishers Pvt. Limited. New Delhi, India, 2003. p. 487-495.

[42] B. D. Kansal, Efeect of domestic and industrial effluents on agricultural productivity. In: G.S. Dhaliwal, B. D. Kansal, (ed.) Management of agricultural Pollution in India. Commonwealth Publishers, New Delhi, India, 1994. p. 157-176.

[43] S. T. Abbas, Salt tolerance in Pakistan Rice varieties through tissue culture. Thesis Doctoral. M.D.S. University, Ajmer, India, 1991.

[44] R. Bhagat, Water in tannery polluted industries. Indian Express, May 27 ${ }^{\text {th }}, 1992$. Chandigarh, India, 1992.

[45] Baruah, A. K., Sharma, R. N., and Borah, G.C., 1993, Input of mills and distillery effluent on water quality of river. Gelabi, Assam., Ind. J. Environ. Health, 35, 288-293.

[46] R. P. Narwal, A. P. Gupta, A. Singh and S. P. S. Karwasra, Pollution potential of some sewage waters of Haryana. In: S.K. Arora, M. Singh, R.P. Aggarwal. (eds.) Recent Advances in Environmental Pollution and Management. H.A.U. Hisar, India, 1990, p. 121-126.

[47] H. F. L. David, G.L. Bela, and A. B. Paul, Environmental Engineers Handbook. $2^{\text {nd }}$ Edition Lewis Publishers, New York, 1996.

[48] Gupta, I. C., and Jain, B. L., 1992, Salinization and alkalinizat ion of groundwater pollution due to textile hand processing industry in Pali., Current Agric., 16, 59-62.

[49] S. K. Gupta and A. Mitra, In: Advances in Land Resource Management for $21^{\text {st }}$ Century, Soil Conservation Society of India, New Delhi, India, 2002. p. 446-460.

[50] A. Morugan, Gracia-Orenes, J. Mataix-Solera, I. Gomez, V. Arcenegui, M.A. Navarro, J. Mataix-Beneyto, Short-term effects of treated waste water irrigation on soil. Two years of study monitoring a Mediterranean calcareous soil, Geophy sical Research Abstracts 11, 2009.

[51] Schipper, L. A, Williamson, J. C., Kettles, H. A., Speir, T. W., 1996, Impact of land applied tertiary-treated effluents on soil biochemical properties., J. Environ. Qual., 25, 1073-1077.

[52] B. D. Kansal and M. P. S. Khurana, Extent of contamination of alluvial soils with cadmium. In. $2^{\text {nd }}$ International conference on Contaminants in soil environment in Australia -Pacific Region, New Delhi, India, 1999. p. 309-310.

[53] Yadav, R. K., Goyal, B., Sharma, R. K., Dubey, S. K., Minhas, P. S., 2002, Post-irrigation impact of domestic sewage effluent on composition of soils, crops and ground water-A case study., Environ. International, 28, 481-486.

[54] Rattan, R. K., Datta, S. P., Chhonkar, P. K., Suribabua, K., Singh, A. K., 2005, Long-term impact of irrigation with sewage effluents on heavy metal content in soils, crops and groundwater-A case study., Agriculture, Ecosystems \& Environ., 109, 310-322.

[55] Nawaz, A., Khurshid, K., Arif, M. S., and Ranjha, A. M., 2006, Accumulation of heavy metals in soil and rice plant (Oryza sativa L.) irrigated with industrial effluents, International J. Agric. \& Bio., 3, 391-393.

[56] Mohammad, M. J., and Mazahreh, N., 2003, Changes in soil fertility parameters in response to irrigation of forage crops with secondary treated wastewater, Commun. Soil Sci. Plant Anal., 34, 1281-1294.

[57] Wang, T. S. C., San-Yae Cheng, and Tung, H., 1967, Dynamics of soil organic acids, Soil Sci., 104, 138-44.

[58] Hayes, A. R., Mancino, C. F., and Pepper, L.L., 1990, Irrigation of Turf grass with Secondary Sewage Effluent: I. Soil and Leachate Water Quality., Agron. J., 82, 939-943.

[59] Zhang, Y. L., Dai, J. L., Wang, R. Q., and Zhang, J., 2008, Effects of long-term sewage irrigation on agricultural soil microbial structural and functional characterizations in Shandong, China., European J. Soil Biol., 44, 84-91.

[60] J.K Friedel, T. Langer, C. Siebe, K. Stahr, Effects of long-term waste water on soil organic matter and microbial biomass and its activities in central Mexico, Biology and Fertility of Soils 31 (2000), 414-421.

[61] C. J. McClean, M. S. Cresser, R. P. Smart, C. Aydinalp, and A. V. Karkat, Unsuitable irrigation practices in the Bursaplain, Turkey. In: Diffuse Pollution and Basin Management: M. Bruen, (ed.). Proceedings of the $7^{\text {th }}$ International Specialized IWA Conference, International Water Association, August $17-21^{\text {st }}, 2003$, Dublin, Ireland, 2003. p. 60-65.

[62] Zalawadia, N. M., Patil, R. G., and Raman, S., 1996, Effect of distillery waste water with fertilizer levels on onion yield and soil properties., J. Ind. Soc. Soil Sci., 44, 802-04.

[63] Subramaniyan, V. K., Nooruddin, T. and Chokkaiya, M., Biodiversity of cynobacteria in industrial effluents, Acta Botanica Malacitana, 32, 27-34.

[64] Mapanda, F., Mangwayana, E. N., Nyamangara, J., and Giller, K. E., 2005, The effect of long-term irrigation using wastewater on heavy metal contents of soils under vegetables in Harare, Zimbabwe, A griculture, Ecosystems \& Environ., 107, 151-165.

[65] Liu, W., Zhao, J., Ouyang, Z., Söderlund, L., and Liu,G., 2005, Impacts of sewage irrigation on heavy metal distribution and contamination in Beijing, China., Environ. International, 31, 805-812.

[66] C. Siebe, Nutrient inputs to soil and their uptake by alfalfa through long-term irrigation with untreated sewage effluent in Mexico, Soil Use Management, CAB International Oxford, 1998. p. 119-122. 
[67] Kürsad Türkdo, M., Kilicel, F., Kara, K., Tuncer, I., and Uygan, I., 2003, Heavy metals in soil, vegetables and fruits in the endemic upper gastrointestinal cancer region of Turkey., Environ. Toxicology \& Pharmacology, 13, 175-179.

[68] Anonymous, Annual Progress Report (2000-03). NATP-MM Project on "Use of Urban and Industrial Effluents in Agriculture”. CSSRI, Karnal-Hary ana, India, 2004.

[69] Sharma, R. K., Agrawal, M., and Fiona, A., 2007, Heavy metal contamination of soil and vegetables in suburban areas of Varanasi, India., Ecotoxicology \& Environ. Safety, 66, 258-266.

[70] Amiri, S. S., Maralian, H., and Aghabarati, A., 2008, Heavy metal accumulation in Melilotus officinalis under crown Olea europaea L. forest irrigated with wastewater., African $\mathrm{J}$. Biotechn., 7, 3912-3916.

[71] Schirado, T., Vergara, L., Schalscha, E. B., Pratt, P. F., 1986., Evidence for movement of heavy metals in a soil irrigated with untreated wastewater., J. Environ. Qual., 15, 9-12.

[72] Lin, C., Negev, I., Eshel, G., and Banin, A., 2008, In Situ Accumulation of Copper, Chromium, Nickel, and Zinc in Soils Used for Long-term Waste Water Reclamation, J. Environ. Qual., 37, 1477-1487.

[73] J. H. J. Ensink, R. W. Simmons, and Van der Hoek, Waste water use in Pak istan: The cases of Haroon abad and Faislabad. International Water Management Institute (IWMI) Research Rep ort. South Asia Regional Office, Patanch, 2003.

[74] Murtaza, G., Gafoor, A., Qadir, M., and Rashid, M. K., 2003, Accumulation and bioavailability of $\mathrm{Cd}, \mathrm{Co}$ and $\mathrm{Mn}$ in soils and vegetables irrigated with city effluent, Pakistan., J. Agric. Sci., 40, 18-24.

[75] Bakhsh, K., Ashraf, M., and Alam, M. W., 2005, Effect of poor quality of ground water on carrot production: A comparative study, J. Agric. Social Sci.,1, 38-40.

[76] Singh, R. P., Singh, V., and Shukla, A. K., 1991, Yield and heavy metal contents of Berseem as influenced by sewage water and refinery effluent., J. Ind. Soc. Soil Sci., 39, 402-404.

[77] C. Uday asoorian, P. Devagi, P. P. Ramaswami, Case study on the utilization of paper and pulp mill effluent irrigation for field crop. In: Proceedings of Workshop on 'Bioremediation of Polluted Habitats', 1999. p. 71-73.

[78] Juwarkar, A. S., and Subramayam, P. V. R., 1986, Impact of pulp and paper mill waste water on crop and soil, Water Sci. Tech., 19, 693-700.

[79] Sharma, V. K., and Kansal, B. D., 1984, Effect of N, farm yard manure, town refuse and sewage water on the yield and $\mathrm{N}$ content of Maize, J. Ecol., 11, 77-81.

[80] Alloway, B. J., Jackson, A. P., and Morgan, H., 1990, The accumulation of cadmium by vegetables grown on soils contaminated from variety of sources, Science of the Total Environ., 91, 233-235.

[81] Hundal, H. S and Arora, C. L., 1993, Studies on toxic trace elements in vegetables and corresponding soils., Ind. J. Horti, 50, 273-278.

[82] Barman, S. C., Kishu, G. C., Salve, P. R., Misra, D., Sahu, R. K., Ramteke, P. W., and Bhargawa, S. K., 2001, Assessment of industrial effluent and its impact on soil and plant., J.
Environ. Biol., 22, 251-256.

[83] Kim, I. S., Kang, H. K., Johnson-Green, P., and Lac, E. J., 2003, Investigation of heavy-metal accumulation in Polygonum thunbergii for phytoextraction., Environ. Poll., 126, 235-243.

[84] Alderfasi, A., 2009, Agronomic and economic impacts of reuse secondary treated wastewater in irrigation under arid and semi-arid regions., World J. Agric. Sci., 5, 369-374.

[85] Adhikari, S., Mitra, A., Gupta, S. K., and Banerjee, S. K., 1998, Pollutant metal contents of vegetables irrigated with sewage water., J. Ind. Soc. Soil Sci., 46, 153-155.

[86] Muchuwetis, M., Birkett, J. W., Chinyanga, E., Zvauya, R., Scrimshaw, M. D., and Lester, J. N., 2006, Heavy metal content of vegetables irrigated with mixtures of wastewater and sewage sludge in Zimbabwe: Implications for human health., Agriculture, Ecosystems \& Environ., 112, 41-48.

[87] Singh, S., and Kumar, M., 2006, Heavy metal load of soil, water and vegetables in peri-urban Delhi, Environ. Monitoring \& Assess, 120, 79-91.

[88] Rothenberg, S. E., Du, X., Zhu, G., and. Jay, J. A., 2007, The impact of sewage irrigation on the uptake of mercury in corn plants (Zea mays) from suburban Beijing., Environ. Poll, 149, 246-251.

[89] Lone, M. I., Saleem, S., Mahmood, T., Saifullah, K., and Hussain, G., 2003, Heavy metal content of vegetables irrigated by sewage/tubewell water., International J. Agric.\& Biol., 4, 533-535.

[90] Brar, M. S., and Arora, C. L., 1997, Concentration of micro-elements and pollutant elements in cauliflower (Brassica oleracea conniver, botrytis var. bortrytis)., Ind. J. Agric. Sci., 67, 141-143.

[91] ISI (Indian Standard Institution). Specifications for drinking and irrigation waters. IS: 10500. New Delhi, India, 1983.

[92] CPCB (Central Pollution Control Board), Pollution Control Acts. Rules and Notifications issued there under. $4^{\text {th }}$ Edition, New Delhi; Central Pollution Control Board, Ministry of Environment and Forests, Government of India, 2001.

[93] M. S. Brar, A. P. Singh, and C. L. Arora, Effect of effluent contaminated water on micro and potentially toxic elements in soils and potato plant. Scientific Registration No.-168, Number of Symposium: 21, 1998.

[94] NEMA (Natural Environmental Management Authority), Ministry of Natural Resources Environmental standards and Preliminary Environmental Impact assessment for water quality and discharge of effluents into water/land. Uganda. Kampala. \{Online\}. Available. http://www.nemaug.org/mon itoring/preliminary $\% 20$ EIA $\% 20 \& 20$ standards $\% 20$ for $\% 20$ wa ter.pdf.

[95] EEC-MPL, (European Economic Commission-maximum permissible levels) Maximum permissible levels for heavy metals. Available at

http:/www.idrc.ca/en/ev-68336-201-1-DO_TOPIC.html., 1997.

[96] FAO (Food and Agriculture Organization), Food for the cities. Food and Agriculture Organization of United Nations, Rome, Italy, 2000.p. 33. 